\title{
ESTUDOS ANATÔMICOS DE RAIZZES GEMÍFERAS DE ESPÉCIES ARBÓREAS E ARBUSTIVAS DE UM FRAGMENTO FLORESTAL EM CAMPINAS (SP), BRASIL
}

\author{
ADRIANA HISSAE HAYASHI \\ Bióloga \\ Orientadora: Profa. Dra. BEATRIZ APPEZZATO-DA-GLÓRIA \\ Dissertação apresentada à Escola Superior de \\ Agricultura "Luiz de Queiroz", Universidade de São \\ Paulo, para obtenção do título de Mestre em \\ Ciências, Área de Concentração: Fisiologia e \\ Bioquímica de Plantas
}

PIRACICABA

Estado de São Paulo - Brasil

Junho - 1998 
Dados Internacionais de Catalogaçāo na Publicaçāo (CIP)

DIVISÃO DE BIBLIOTECA E DOCUMENTAÇÃO - Campus "Luiz de Queiroz"/USP

Hayashi, Adriana Hissae

Estudos anatômicos de raizes gemiferas de espécies arbóreas e arbustivas de um fragmento florestal em Campinas (SP), Brasil / Adriana Hissae Hayashi. - - Piracicaba, 1998.

63 p. : il.

Dissertaçāo (mestrado) - - Escola Superior de Agricultura Luiz de Queiroz, 1998. Bibliografia.

1. Anatomia vegetal 2. Espécie florestal 3. Gema 4. Propagaçāo vegetal 5. Sistema radicular I. Título

CDD 634.97 
Dedico este trabalho aos meus pais, shinsaku $e$ Kazuko, com muito amor $e$ carinho. 


\section{AGRADECIMENTOS}

À Profa. Dra. Beatriz Appezzato-da-Glória, pela amizade e valiosa orientação e pelos ensinamentos transmitidos durante a realização deste trabalho.

Ao Prof. Dr. Ricardo R. Rodrigues do Depto de Botânica da ESALQ, pela identificação do material botânico e pelas valiosas idéias que motivaram este estudo.

À bióloga e amiga Alessandra dos Santos Penha, pela amizade e pelo incentivo e companheirismo durante a realização do trabalho de campo.

Ao PqC Dr. Luiz Antonio Ferraz Matthes do Centro de Horticultura III do Instituto Agronômico de Campinas, por possibilitar a realização do trabalho na mata Santa Elisa, Campinas (SP).

Aos Profs. Dr. Gilberto B. Kerbauy do Depto de Botânica do Instituto de Biociências, USP e Dr. Mário Tomazello Filho do Depto de Ciências Florestais da ESALQ, pelas valiosas sugestões prestadas no decorrer deste trabalho.

Ao Sr. Sebastião J. Albuquerque e aos demais funcionários do campo do Centro de Horticultura III do Instituto Agronômico de Campinas, pelo auxílio prestado durante o trabalho de campo.

À farmacêutica Sra. Marli K. M. Soares, técnica do Laboratório de Anatomia Vegetal do Depto de Botânica da ESALQ, pela amizade e pelo apoio técnico durante as atividades práticas.

Ao Prof. Dr. Ricardo Ferraz de Oliveira do Depto de Botânica da ESALQ, pela colaboração prestada na atividade de campo e na revisão do "Summary".

Ao Prof. Sergius Gandolfi do Depto de Botânica da ESALQ, por possibilitar a coleta de material vegetal na sua área de estudo na Reserva Florestal de Santa Genebra, Campinas (SP).

Ao Francisco Carlos Antoniolli, funcionário do Depto de Botânica da ESALQ, pelo apoio técnico durante a coleta do material vegetal. 
Ao Prof. Dr. Elliot W. Kitajima do Núcleo de Apoio à Pesquisa - Microscopia Eletrônica na Pesquisa Agropecuária (NAP-MEPA) da ESALQ, por ter possibilitado o processamento do material para microscopia eletrônica de varredura.

Ao Srs. Osvaldo J. S. Soares e Luiz F. V. Servin, pelos registros fotográficos das estacas radiculares.

A bibliotecária Beatriz H. Giongo, pela revisão das referências bibliográficas.

Aos pesquisadores e funcionários do Centro de Horticultura III do Instituto Agronômico de Campinas, pela amizade e pelo constante apoio.

Aos amigos do Curso de Pós-Graduação em Fisiologia e Bioquimica de Plantas, pela amizade e companheirismo durante o curso.

Aos professores e funcionários do Depto de Botânica da ESALQ, pela amizade e pelos auxilios prestados.

À Coordenação do Curso de Pós-Graduação em Fisiologia e Bioquimica de Plantas, por ter possibilitado a realização do presente trabalho.

À amiga e bióloga Juliana A. Fernando, pela revisão final do texto, mas principalmente pela amizade.

À minha irmã Telma, pelos auxilios prestados em várias etapas deste trabalho, mas principalmente pelo incentivo e pela compreensão, e à minha irmã Paula e à minha sobrinha Carolina, pelo carinho.

Aos meus pais, Shinsaku e Kazuko, pelo carinho e pelo constante apoio.

Ao Conselho Nacional de Desenvolvimento Científico e Tecnológico (CNPq), pela bolsa concedida.

À Fundação de Amparo à Pesquisa do Estado de São Paulo (FAPESP), pelo financiamento do trabalho.

$E$ a todos que, direta ou indiretamente, contribuiram para a realização deste trabalho. 


\section{SUMÁRIO}

Página

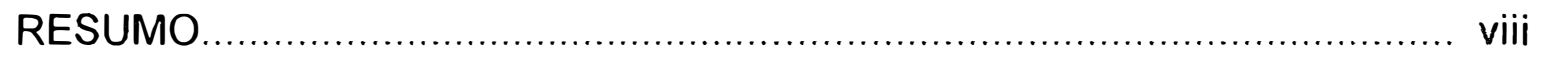

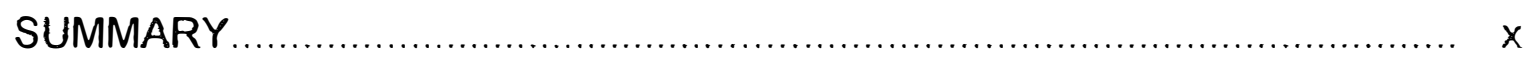

1 INTRODUÇÃO

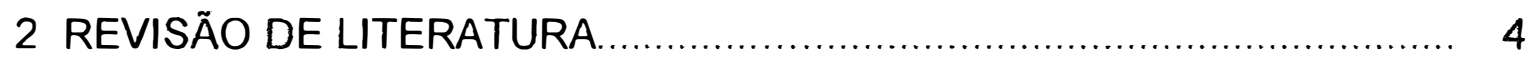

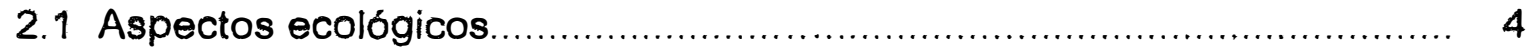

2.2 Estudos anatômicos .................................................................... 7

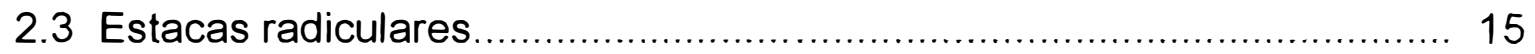

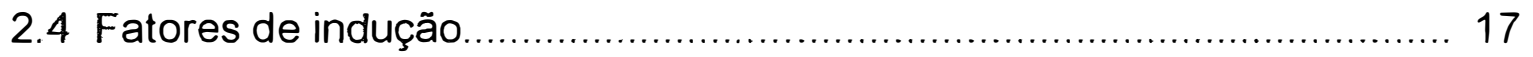

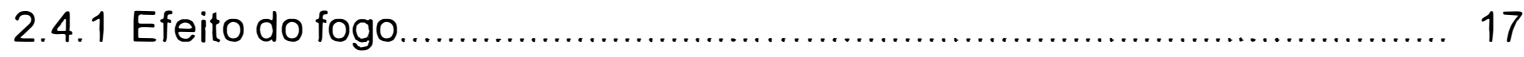

2.4.2 Lesão ou injúria do sistema radicular ............................................ 19

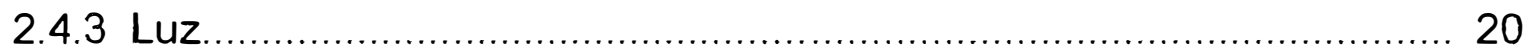

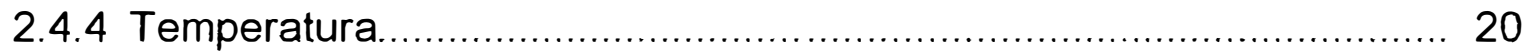

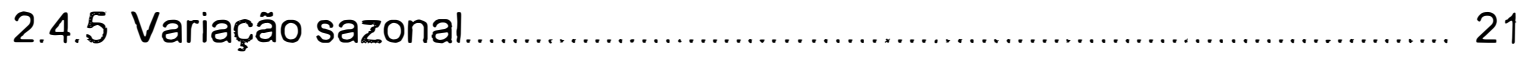

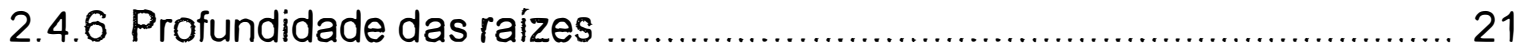

2.4.7 Comprimento da estaca radicular ................................................ 21

2.4.8 Efeito dos reguladores de crescimento ....................................... 22

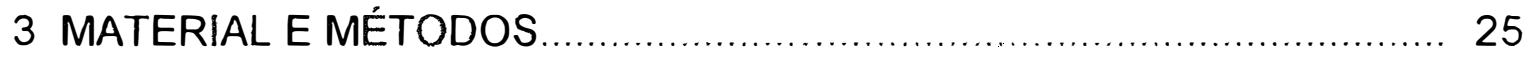

3.1 Caracterização das áreas de estudo .................................................. 25

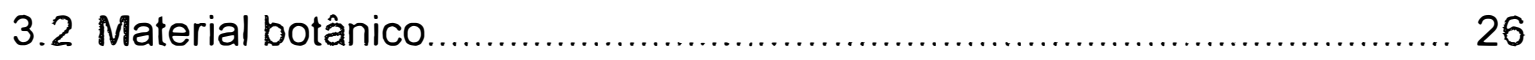

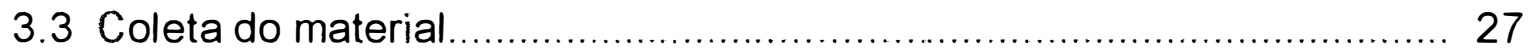

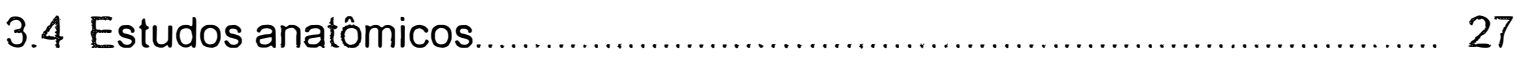




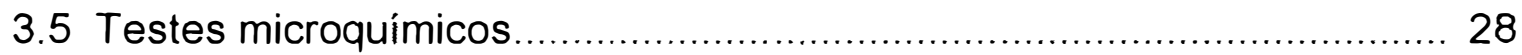

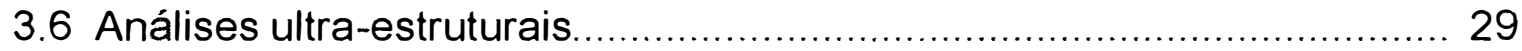

3.7 Simulação da ação do fogo na indução de gemas................................. 29

3.8 Simulação da injúria mecânica na indução de gemas............................ 30

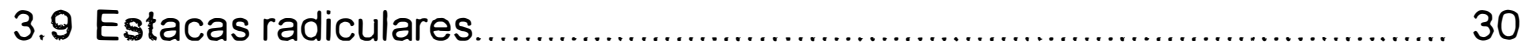

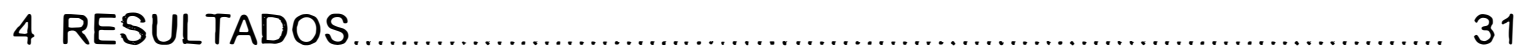

4.1 Estudos anatômicos, microquímicos e ultra-estruturais........................ 31

4.2 Simulação da ação do fogo na indução de gemas................................. 34

4.3 Simulação da injúria mecânica na indução de gemas............................ 34

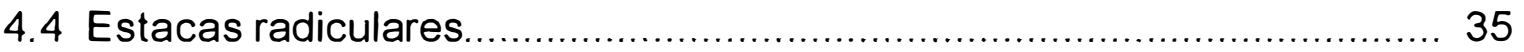

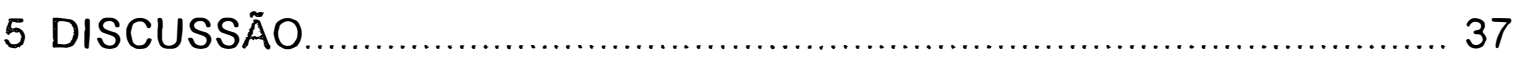

6 CONCLUSÕES

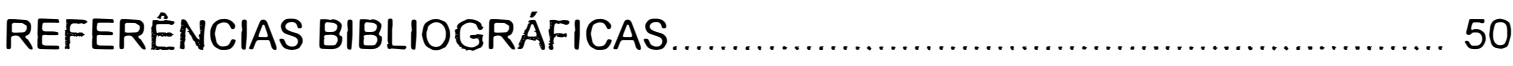

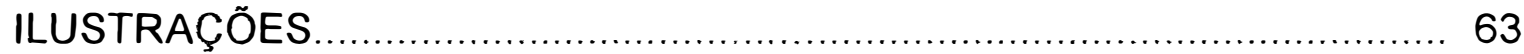




\title{
ESTUDOS ANATÔMICOS DE RAIZZES GEMÍFERAS DE ESPÉCIES ARBÓREAS E ARBUSTIVAS DE UM FRAGMENTO FLORESTAL EM CAMPINAS (SP), BRASIL
}

\author{
Autora: ADRIANA HISSAE HAYASHI \\ Orientadora: Profa. BEATRIZ APPEZZATO-DA-GLÓRIA
}

\section{RESUMO}

Através de um levantamento realizado num fragmento de floresta mesófila semidecídua, que possui um histórico de perturbação por fogo, verificou-se que oito espécies arbóreas e arbustivas (Bauhinia forficata Link, Centrolobium tomentosum Guill. ex Benth., Esenbeckia febrifuga (St. Hil.) Juss. ex Mart., Inga fagifolia Willd., Lonchocarpus cultratus (Vell.) A.M.G. Azevedo \& H.C. Lima, Machaerium stipitatum (D.C.) Vog., Mollinedia schottiana (Spreng.) Perk. e Polygala klotzschii Chad.) formaram brotos a partir de sistemas subterrâneos superficiais. Os estudos anatômicos confirmaram a natureza radicular dos sistemas gemiferos e testes microquimicos caracterizaram as reservas que poderiam estar disponíveis para o processo de iniciação das gemas. Paralelamente, realizou-se estudos sobre o desenvolvimento das gemas radiculares em $M$. schottiana, $M$. stipitatum e $C$. tomentosum. Nas três espécies estudadas, as gemas eram reparativas e não adicionais e possuiam origem endógena em $M$. schottiana e $C$. tomentosum e exógena em $M$. stipitatum. A fim de avaliar se as gemas radiculares eram induzidas pelo fogo 
ou por injúrias mecânicas, as duas espécies que apresentaram maior capacidade para formar gemas radiculares, C. tomentosum e $M$. stipitatum, foram selecionadas para os experimentos de simulação da ação do fogo e da injúria mecânica. Ambos os experimentos não induziram a formação de gemas radiculares durante os doze meses que se seguiram à sua instalação. As duas espécies referidas anteriormente foram capazes de produzir gemas adventícias a partir de estacas radiculares e exibiram padrões distintos na formação destas gemas. Em C. tomentosum, as gemas formaram-se exclusivamente na extremidade proximal da estaca, enquanto as gemas de $M$. stipitatum formaram-se ao longo de toda a estaca. 


\title{
ANATOMICAL STUDIES OF ROOT SUCKERS OF TREES AND SHRUBS SPECIES OF A FOREST FRAGMENT IN CAMPINAS (SP), BRAZIL
}

\author{
Author: ADRIANA HISSAE HAYASHI \\ Adviser: Prof. BEATRIZ APPEZZATO-DA-GLÓRIA
}

\section{SUMMARY}

On a survey realized in a fragment of semideciduous mesophytic forest which had been disturbed by fire, it was verified that eight trees and shrubs species (Bauhinia forficata Link, Centrolobium tomentosum Guill. ex Benth., Esenbeckia febrifuga (St. Hil.) Juss. ex Mart., Inga fagifolia Willd., Lonchocarpus cultratus (Vell.) A.M.G. Azevedo \& H.C. Lima, Machaerium stipitatum (D.C.) Vog., Mollinedia schottiana (Spreng.) Perk. e Polygala klotzschii Chad.) produced shoot buds on the superficial subterranean systems. Anatomical studies of those systems confirmed their root nature and the histochemical tests identified the reserves which could be used for bud sprouting. Simultaneously, anatomical studies of $C$. tomentosum, $M$. schottiana and $M$. stipitatum adventitious buds allowed to conclude that they were reparative and not additional buds. Root buds of $M$. schottiana and $C$. tomentosum had endogenous origin but in $M$. stipitatum they were exogenous. 
In order to evaluate whether the root buds were induced by fire or by mechanical injuries, two species that showed higher number of buds on roots, C. tomentosum and $M$. stipitatum, were selected for fire and mechanical injuries simulation experiments. None of the experiments induced root bud formation during twelve months after their instalation. Root cuttings from these two species showed different patterns of bud formation. In C. tomentosum, buds were originated only in the proximal end of the cutting but in $M$. stipitatum they were originated along the cutting. 


\section{INTRODUÇÃO}

A formação de gemas em raizes e seu posterior desenvolvimento em caules aéreos são fenômenos observados em muitas espécies vegetais (Bell, 1993; Peterson, 1975; Priestley \& Swingle, 1929; Raju et al., 1966).

O comportamento invasor de determinadas plantas pode ser atribuido, em parte, à habilidade de se propagar através das gemas adventícias formadas em suas raizes (Baird et al., 1992; Charlton, 1966; Raju et al., 1966), as quais dificultam sua erradicação (Baird et al., 1992; Coupland et al., 1955). Conseqüentemente, métodos sobre cultivo e tratamentos químicos (Baird et al., 1992; Kefford \& Caso, 1972) têm sido estudados com a finalidade de impedir a iniciação e o desenvolvimento de gemas radiculares em espécies invasoras (Peterson, 1975).

O desenvolvimento de gemas em raizes também assume um importante papel na propagação vegetativa de espécies de interesse econômico, como plantas frutiferas e ornamentais, através da utilização de estacas radiculares (Browse, 1979; Dirr \& Heuser, 1987; Hartmann et al., 1990; Hudson, 1953, 1954, 1955; Mahlsted \& Harber, 1957; Siegler \& Bowman, 1939). Em plantas lenhosas, a propagação vegetativa através de gemas radiculares é de baixa ocorrência quando comparada à observada em plantas herbáceas (Jenik, 1994). Leakey (1985), porém, observa que a capacidade das espécies arbóreas de se reproduzirem assexuadamente deve ser, teoricamente, semelhante à das plantas herbáceas. Segundo o mesmo autor, esta capacidade pode variar entre os individuos de uma mesma espécie e entre 
espécies, podendo ser influenciada pela situação do indivíduo no ambiente e pelo seu estado fisiológico.

Estudos anatômicos, fisiológicos e ecológicos das raizes gemiferas têm sido realizados, principalmente, em espécies herbáceas invasoras (Baird et al., 1992; Bakshi \& Coupland, 1959; Bowen \& Pate, 1993; Myers et al., 1964; Polowick \& Raju, 1982; Raju et al., 1966), arbustivas de ambientes savânicos (Achutti, 1978; Paviani, 1987; Paviani \& Magalhães, 1996) e arbóreas de clima temperado (Brown, 1974; Burrows, 1990; Jeník, 1994; Paukkonen et al., 1992; Sandberg, 1951; Schier, 1973a,b; Siegler \& Bowman, 1939). Tais estudos são escassos em espécies arbóreas de ambientes tropicais (Aidar, 1992; Castellani, 1986; Greig \& Mauseth, 1991; Lacey \& Johnston, 1990; Matthes, 1992; Rodrigues et al., 1990; Uhl, 1982), sendo que estudos anatômicos das gemas radiculares de espécies da floresta tropical brasileira são inexistentes.

O fenômeno da formação de gemas radiculares é freqüentemente observado em ambientes perturbados, principalmente pela ação do fogo, tanto para ambientes savânicos como para outros habitats terrestres (Rizzini \& Heringer, 1966). O brotamento radicular de espécies arbóreas, constatado por Castellani (1986), Matthes (1992), Rodrigues et al. (1990) e Uhl (1982), ocorreu em áreas de floresta tropical após a ocorrência de fogo. Características de resposta ao fogo também têm sido estudadas em espécies do sudoeste da Austrália, visto que este fator constitui uma das maiores influências na vegetação de ecossistemas do tipo Mediterrâneo (Bell et al., 1996).

Uma vez que algumas plantas são capazes de formar gemas radiculares como um processo natural de crescimento, enquanto outras necessitam de estímulo para o início da formação dessas gemas (Browse, 1979), vários fatores podem estar envolvidos na sua iniciação. Deste modo, tem-se verificado a influência da temperatura (Baird et al., 1992; Baskin \& Baskin, 1990), do corte da parte aérea da planta (Farmer, 1962; Paukkonen et al., 1992), de injúrias mecânicas na raiz (Baird et al., 1992; Bell, 1993; Burrows, 
1990; Rizzini \& Heringer, 1966) e da exposição da raiz à luz (Brown, 1974; Carlson et al., 1964; Charlton, 1965) na iniciação das gemas radiculares.

Os trabalhos encontrados na literatura, que se referem à formação de gemas em raizes de florestas tropicais brasileiras (Aidar, 1992; Castellani, 1986; Matthes, 1992; Rodrigues et al., 1990; Uhl, 1982), basearam-se em observações morfológicas externas dos sistemas subterrâneos. Visto que a maioria dos estudos sobre raízes gemíferas está baseada principalmente neste tipo de observação, é necessária a realização de estudos anatômicos que confirmem a estrutura radicular destes sistemas subterrâneos (Raju et al., 1966; Rizzini \& Heringer, 1966). Além dos estudos anatômicos sobre a iniciação e o desenvolvimento de gemas em raízes, também é interessante a realização de estudos fisiológicos sobre os possiveis fatores que controlam a formação destas gemas.

Deste modo, o presente trabalho foi conduzido com a finalidade de:

- identificar as espécies arbóreas e arbustivas capazes de formar gemas em sistemas subterrâneos superficiais em um fragmento de floresta mesófila semidecidua, após a ocorrência de fogo;

- confirmar a natureza radicular dos sistemas subterrâneos gemiferos;

- identificar os compostos de reserva dos sistemas radiculares;

- estudar a origem e a ultra-estrutura das gemas radiculares adventícias de três espécies arbóreas;

- verificar alguns dos possíveis fatores envolvidos na indução das gemas radiculares através da simulação de queimada na raiz, da retirada parcial da casca da raiz e da confecção de estacas radiculares. 


\section{REVISÃO DE LITERATURA}

\subsection{Aspectos ecológicos}

O fenômeno da formação de gemas em sistemas radiculares não é uma característica peculiar de algumas plantas, podendo ser observado em espécies de diferentes categorias taxonômicas, desde pteridófitas até angiospermas (Lacey \& Johnston, 1990; Peterson, 1970). Estas espécies ocorrem em diferentes formações vegetais das zonas áridas e semi-áridas, regiões de monções, de floresta pluvial tropical e temperada e regiões pantanosas e subalpinas (Lacey \& Johnston, 1990).

Muitas espécies lenhosas apresentam potencial para formar eixos caulinares a partir de gemas adventícias em raízes (Lacey \& Johnston, 1990). Entretanto, a ocorrência desse fenômeno é muito mais comum entre espécies herbáceas, principalmente as que apresentam comportamento invasor (Baird et al., 1992; Bakshi \& Coupland, 1960; Bonnett \& Torrey, 1966; Charlton, 1965, 1966; Myers et al., 1964; Polowick \& Raju, 1982; Raju et al., 1966).

O termo 'woody clump' tem sido utilizado para definir um conjunto de caules lenhosos originados a partir de estruturas subterrâneas, como as raízes, devido a perda da dominância apical do caule principal (Lacey \& Johnston, 1990).

Em espécies arbóreas, as gemas radiculares podem ser produzidas em qualquer estágio do seu ciclo de vida, mas somente sob circunstâncias especiais poderão tornar-se árvores adultas individuais (Koop, 1987). Em 
algumas espécies, os brotos radiculares apresentam a capacidade de desenvolver seu próprio sistema radicular (Greig \& Mauseth, 1991; Jeník, 1994; Koop, 1987). Entretanto, de acordo com Lacey \& Johnston (1990), as raizes podem ser iniciadas pelos brotos radiculares ou pela raiz-mãe, nas proximidades da base do novo caule. Os brotos que possuem pouca ou nenhuma capacidade de desenvolver seu próprio sistema radicular utilizam, indefinidamente, o sistema radicular da planta-mãe. Por exemplo, na herbácea invasora Linaria vulgaris, novas raízes originam na raiz-mãe ao redor dos brotos (Charlton, 1966) enquanto que na espécie arbórea Populus tremuloides, raizes têm sido observadas originar na raiz-mãe e na base do novo broto (Sandberg, 1951).

Uma classificação do sistema de regeneração, que relaciona o comportamento entre a planta-mãe e os brotos provenientes das gemas radiculares, tem sido proposta por Hudson (1955):

- Tipo A: corresponde aos brotos radiculares que crescem próximos à plantamãe, na qual eles normalmente permanecem ligados, formando uma parte integral da planta original;

- Tipo B: abrange os brotos originados em raizes não injuriadas, a alguma distância da planta-mãe, sendo que, posteriormente, a região radicular de conexão morre após os brotos estarem estabelecidos;

- Tipo C: neste tipo, os brotos raramente são produzidos, exceto em resposta à injúria da raiz, embora as raizes não estejam totalmente separadas da planta-mãe;

- Tipo D: compreende as novas plantas formadas a partir de raizes desligadas da planta-mãe, desde que estas permaneçam 'in situ', sem distúrbio do sistema radicular assimilatório;

- Tipo E: relaciona-se a fragmentos de raízes (estacas radiculares) capazes de produzir novas plantas; 
- Tipo F: corresponde às raízes capazes de regenerar somente após tratamento especial;

- Tipo G: denominação dada às plantas incapazes de produzir brotos radiculares sob quaisquer circunstâncias.

As raizes gemiferas podem originar um grupo de plantas cujo sistema radicular permanece conectado ativamente (Bell, 1993) ou se separa com a morte ou decomposição do tecido de conexão que liga o broto à planta-mãe (Lacey \& Johnston, 1990; Rodrigues et al., 1990), como em Liquidambar styraciflua (Brown, 1974). O tamanho do 'woody clump' formado pelo brotamento radicular, de acordo com Lacey \& Johnston (1990), é altamente variável dentro e entre espécies, sendo que o maior 'woody clump' conhecido ocorre no oeste dos Estados Unidos, constituido por mais de 47.000 caules de Populus tremuloides, que recobrem uma área total de 43 ha. Deste modo, a ocorrência de raizes gemíferas pode resultar na formação de populações com distribuição espacial agregada, como verificado por Aidar (1992), que pode modificar muitos aspectos da dinâmica de comunidades, principalmente em relação aos estudos fitossociológicos (Rodrigues et al., 1990).

Do ponto de vista genético, o genótipo do 'woody clump' é mantido indefinidamente ou, ao menos, por várias gerações (Lacey \& Johnston, 1990) e, conseqüentemente, a reprodução sexuada é necessária para a manutenção da variabilidade genética dentro da comunidade vegetal (Rood et al., 1994). Por outro lado, brotos originados de raízes gemíferas apresentam maior capacidade de exploração de recursos e, portanto, maior competitividade na ocupação da área (Lacey \& Johnston, 1990). Estes brotos adventícios possuem vantagens em relação às plântulas originadas de sementes, pois podem receber suprimento contínuo de água e nutrientes da planta-mãe (Greig \& Mauseth, 1991; Hudson, 1955; Janzen, 1980).

A ocorrência de raízes gemiferas tem sido descrita por Rizzini (1965) e Rizzini \& Heringer $(1962,1966)$ em plantas do cerrado, que apresentam como 
característica a facilidade de propagar-se vegetativamente através de seus sistemas subterrâneos em decorrência das perturbações ambientais, como o fogo e a seca. Coupland et al. (1955) verificaram que a formação de gemas radiculares em Euphorbia esula é estimulada principalmente após a parte aérea da planta ser morta através do corte ou da aplicação de herbicidas.

\subsection{Estudos anatômicos}

A ocorrência da formação de gemas em raizes tem sido verificada em numerosas espécies vegetais, porém estes sistemas subterrâneos raramente são submetidos a análises anatômicas que confirmem sua natureza radicular (Raju et al., 1966; Rizzini \& Heringer, 1966).

Dentre as várias plantas capazes de originar gemas radiculares, poucas espécies lenhosas foram anatomicamente estudadas, como Araucaria cunninghamii (Burrows, 1990), Malus pumila (Siegler \& Bowman, 1939), Populus tremuloides (Sandberg, 1951; Schier, 1973a) e Tamarix petandra (Wilkinson, 1966). A maioria dos estudos tem dado ênfase às plantas herbáceas, principalmente invasoras (Baird et al., 1992; Bakshi \& Coupland, 1960; Bonnett \& Torrey, 1966; Charlton, 1965, 1966; Myers et al., 1964; Polowick \& Raju, 1982; Raju et al., 1966).

Os sítios de iniciação de gemas em raizes variam amplamente entre as espécies e, de acordo com Peterson (1975), diversos tecidos da raiz podem estar envolvidos na formação do primórdio de gema. Conseqüentemente, os padrões de desenvolvimento variam consideravelmente dependendo da região da raiz na qual ocorre a iniciação da gema.

Peterson (1975) reconhece 6 sítios de iniciação de gemas em raízes: (1) periciclo (Bonnett \& Torrey, 1966; Myers et al., 1964; Taylor, 1926; Sandberg, 1951); (2) felogênio e outros tecidos derivados do periciclo (Appezzato-daGlória \& Estelita, 1995; Bakshi \& Coupland, 1959; Burrows, 1990; Murray, 
1957); (3) córtex, relacionado às raizes laterais (Baird et al., 1992; Bakshi \& Coupland, 1960; Charlton, 1965, 1966; Polowick \& Raju, 1982; Wilson, 1927); (4) córtex, não relacionado às raizes laterais (Bell, 1993; Wardlaw, 1953); (5) ápice radicular (Peterson, 1970); (6) calo radicular (Bell, 1993; Lacey \& Johnston, 1990; Priestley \& Swingle, 1929).

Em raizes de gimnospermas e angiospermas, o periciclo geralmente corresponde ao sítio de iniciação dos primórdios da raiz lateral (Esau, 1965; Priestley \& Swingle, 1929). Entretanto, o periciclo também pode ser o sitio de iniciaçăo de gemas radiculares de muitas espécies, como Acanthus montanus (Taylor, 1926), Populus tremuloides (Sandberg, 1951) e Tamarix petandra (Wilkinson, 1966).

Em raizes de Euphorbia esula (Bakshi \& Coupland, 1959), primórdios de gema e raiz originaram a partir de um meristema pericíclico, o qual formou um anel contínuo denominado pelos autores de câmbio pericíclico. Nos estágios iniciais do desenvolvimento, um primórdio de gema dificilmente pôde ser distinguido morfologicamente de um primórdio de raiz até a sua emergência da raiz-mãe. Conseqüentemente, foi sugerido que os primórdios, antes da emergência, seriam potencialmente capazes de formar gemas ou raízes (Bakshi \& Coupland, 1959). Entretanto, Myers et al. (1964) verificaram que, nesta mesma espécie, segmentos radiculares cultivados in vitro desenvolveram primórdios de raiz e gema no periciclo, com os primórdios sendo identificados antes da sua emergência através da epiderme. A conexão vascular resultou da diferenciação centrípeta do procâmbio da gema, que estabeleceu sua continuidade com o sistema vascular da raiz principal.

De acordo com Bonnett \& Torrey (1966), embora os estágios iniciais da formação dos primórdios de gema e raiz lateral se mostrassem semelhantes em Convolvulus arvensis, o posterior desenvolvimento dos primórdios revelou diferenças quanto à participação dos tecidos da raiz primária, às taxas de desenvolvimento, ao comportamento da endoderme e em relação aos padrões 
celulares de organização. Estes autores ainda discutem a existência, na raiz, de um primórdio indeterminado capaz de se desenvolver em gema ou raiz lateral. Em Asclepias syriaca, Polowick \& Raju (1982) verificaram que os primórdios de gema e raiz lateral podem ser identificados no estágio inicial do desenvolvimento, antes que emerjam da raiz-mãe, assim como observado por Appezzato (1988) em Mandevilla velutina.

A formação de gemas radiculares que se originam a partir do felogênio ou de tecidos derivados do periciclo ocorre somente em poucas espécies vegetais (Priestley \& Swingle, 1929).

Estudando os aspectos anatômicos do desenvolvimento de gemas radiculares em Araucaria cunninghamii, Burrows (1990) verificou que as gemas originavam no parênquima resultante de divisões do periciclo. Durante a formação da gema, houve a organização de uma lacuna acima do meristema apical pela separação das paredes celulares. Os primórdios foliares desenvolviam-se a partir do meristema apical, mas algumas das folhas que circundavam o meristema pareciam ser derivadas da desdiferenciação de células do córtex secundário. Segundo o autor, o córtex secundário de Araucaria cunninghamii corresponde à região localizada entre o câmbio vascular e o felogênio, constituído por floema secundário, parênquima derivado do periciclo, floema primário e feloderme. Concomitante com a formação e o desenvolvimento da gema, uma proliferação do córtex secundário e do câmbio vascular ocorreu nas proximidades do primórdio de gema. A conexão vascular da gema ao estelo ocorreu por desdiferenciação do cilindro provascular.

Murray (1957), ao estudar a ontogenia de brotos adventícios em raízes de alfafa (Medicago sativa $\times$ M. falcata), observou a ocorrência de atividade meristemática no felogênio, que levou a formação de um domo primordial, no qual uma ou mais gemas foram iniciadas. Deste modo, durante a ontogênese do primórdio de gema, a raiz passou por duas fases relevantes. A primeira fase correspondeu à iniciação e ao desenvolvimento de um domo primordial na 
periferia da raiz. A segunda, à diferenciação de células parenquimáticas do floema secundário subjacente para a formação de uma zona meristemática, na qual tecidos vasculares se diferenciaram e conectaram o primórdio ao câmbio da raiz.

Existe uma discussão em relação ao fato da gema radicular adventícia ser endógena ou exógena quanto a sua origem. De acordo com Priestley \& Swingle (1929), embora alguns dos tecidos derivados do periciclo sejam superficiais, as gemas iniciadas por eles devem ser consideradas como endógenas pois, em última análise, estes tecidos são derivados do periciclo. Por outro lado, Bell (1993) e Brown (1974) consideram gemas de origem endógena quando formadas no periciclo, como as raizes laterais, e gemas exógenas se originadas de tecidos externos ao estelo.

Primórdios de gema podem desenvolver-se adjacentes às raizes laterais, como observado em Asclepias syriaca (Polowick \& Raju, 1982), Diodia virginiana (Baird et al., 1992), Linaria vulgaris (Bakshi \& Coupland, 1960; Charlton, 1965,1966) e Roripa austriaca (Wilson, 1927). Mais de uma gema pode estar situada na base de uma única raiz lateral (Polowick \& Raju, 1982).

Os sítios de iniciação dos meristemas de gema formados adjacentes às raizes laterais são variados, incluindo o periciclo (Polowick \& Raju, 1982), felogênio da raiz principal (Dore, 1955; Priestley \& Swingle, 1929), córtex da raiz principal (Baird et al., 1992; Bakshi \& Coupland, 1960; Priestley \& Swingle, 1929) ou em tecidos mais externos da própria raiz lateral quando ela ainda se encontra no interior da raiz-mãe (Charlton, 1966; Priestley \& Swingle, 1929).

Baird et al. (1992) relataram que, em Diodia virginiana, o desenvolvimento dos tecidos vasculares secundários, da periderme e do parênquima de reserva de amido coincidiu com a formação das gemas adventícias. Estas gemas originaram-se individualmente ou em grupos nas raízes, a partir do parênquima de reserva de amido, sendo que muitas destas gemas estavam associadas às raízes laterais. 
Em Linaria vulgaris (Bakshi \& Coupland, 1960), o primórdio de gema originou-se no parênquima do córtex primário da raiz-mãe, sempre adjacente a uma raiz lateral. Charlton (1965) confirmou que a iniciação de gemas radiculares desta espécie ocorria na junção da raiz-mãe com as raízes laterais. Num trabalho posterior, Charlton (1966) observou que a demarcação do tecido das raizes mãe e lateral geralmente não era evidente, mas onde a distinção foi clara, as gemas originavam-se nas camadas mais externas da raiz lateral.

Dore (1955) constatou, em Roripa armoracia, que os meristemas organizados ocorriam no felogênio da raiz principal, associados às cicatrizes de raizes laterais. Tais meristemas poderiam se desenvolver em gemas ou raizes, dependendo das condições fisiológicas prevalecentes no periodo de desenvolvimento.

Algumas explicações foram sugeridas para justificar essa associação entre gemas adventícias e raízes laterais. Segundo Priestley \& Swingle (1929), o rompimento da endoderme, decorrente da pressão mecânica exercida pelo desenvolvimento das raizes laterais, provocaria um vazamento de água e solutos em direção ao córtex, que favoreceria a atividade meristemática nessa região. A ausência de formação de gema, em muitos casos, aparentemente, ocorria devido à continuidade da endoderme entre a raiz lateral e a raiz-mãe. Entretanto, em Linaria vulgaris, foi verificado que a endoderme da raiz-mãe permaneceu contínua à da raiz lateral durante o desenvolvimento deste e, mesmo assim, esta espécie foi capaz de formar gemas adjacentes a raiz lateral. Portanto, o vazamento de água e solutos para o córtex pareceu não exercer grande conseqüência para esta espécie (Bakshi \& Coupland, 1960). Por outro lado, Baird et al. (1992) sugeriu que esta associação entre gema e raiz lateral estava relacionada, em parte, a enzimas e hormônios de crescimento que, liberados pela coifa da raiz lateral em desenvolvimento, estimulariam a formação da gema. 
Em Ophioglossum vulgatum, células parenquimáticas do córtex radicular constituiram um sítio potencial para o desenvolvimento de gemas radiculares, as quais podiam distribuir-se casualmente ao longo da raiz. A iniciação das gemas ocorreu quando um grupo de células parenquimáticas corticais começou a se dividir até a formação de uma massa meristemática de células, na qual um primórdio de gema se organizou. Posteriormente, teve início o desenvolvimento do primórdio foliar e a diferenciação basípeta das células parenquimáticas em tecidos vasculares, conectando a gema ao estelo da raiz (Wardlaw, 1953).

Poucas plantas têm a capacidade de formar gemas radiculares próximas ao ápice da raiz (Bell, 1993). Raizes de Ophioglossum petiolatum desenvolveram gemas no ápice radicular, principalmente, a partir das derivadas recentes da célula apical (Peterson, 1970).

Em muitas espécies vegetais, gemas radiculares também podem ser formadas em proliferações de calo, somente após o sistema radicular ter sido injuriado ou tratado (Bell, 1993; Lacey \& Johnston, 1990; Priestley \& Swingle, 1929).

Os primórdios de gema de Malus pumila, de acordo com Siegler \& Bowman (1939), foram resultantes da atividade meristemática das células do parênquima do raio floemático, evidenciadas por apresentarem paredes celulares muito finas e núcleo conspícuo. Estas células sofreram divisões e formaram um pequeno grupo de células, constituindo o primórdio de gema.

Gemas radiculares também podem originar-se a partir da epiderme, como em Roripa austriaca (Wilson, 1927), e da exoderme (Priestley \& Swingle, 1929).

Espécies do cerrado brasileiro também possuem diferentes sitios de iniciação de gemas radiculares. Em Piptocarpha rotundifolia, Achutti (1978) verificou que as gemas adventicias formaram-se na região cortical da raiz, com inúmeros pêlos glandulares e tectores recobrindo-as. Kirizawa (1981) observou que, após o seccionamento da raiz, as gemas radiculares de Cochlospermum 
regium originaram-se no parênquima do floema e, às vezes, no parênquima radial desse tecido vascular $e$, em conseqüência desse fator, o câmbio mostrou-se alterado na zona em questão. Estudando a anatomia do desenvolvimento do xilopódio de Brasilia sickii, Paviani (1987) constatou que este sistema subterrâneo era constituído pela raiz principal e pelo hipocótilo, onde ocorria a formação de gemas adventícias através da desdiferenciação de células localizadas superficialmente. Appezzato-da-Glória \& Estelita (1995) verificaram que as raízes tuberosas de Mandevilla velutina e $M$. illustris, quando seccionadas, formaram gemas após 50 dias. Em M. velutina, as gemas localizaram-se preferencialmente na região central da raiz, provenientes de divisões do câmbio vascular e, em $M$. illustris, nas regiões central e periférica, provenientes, respectivamente, de divisões do câmbio vascular e do câmbio vascular de nódulos vasculares no parênquima cortical.

Estas gemas radiculares podem permanecer em dormência até que recebam algum estímulo para se desenvolverem em brotos ou podem se desenvolver em eixos caulinares logo após a sua formação (Brown, 1974, Lacey \& Johnston, 1990; Polowick \& Raju, 1982). Em Populus tremuloides, caules originaram-se de gemas pré-formadas ou neoformadas ou ainda por meio de pequenos caules suprimidos (Sandberg, 1951; Schier, 1973a).

A iniciação de gemas em sistemas subterrâneos está parcialmente relacionada aos compostos de reserva. Dentre os compostos de reserva armazenados pelas plantas, os carboidratos ocupam uma posição de destaque (Dietrich \& Figueiredo-Ribeiro, 1986; Dietrich et al., 1988). O amido é o mais abundante carboidrato de reserva nas plantas e, sendo insolúvel em água, pode ser estocado nas células vegetais em grande quantidade.

O nivel de carboidratos foi ineficaz ou teve um pequeno papel na formação de gemas em segmentos radiculares (Charlton, 1965; Kefford \& Caso, 1972). Entretanto, em plantas ainda no início do período de crescimento 
e desenvolvimento, os carboidratos constituem um fator limitante para o crescimento dos brotos em sistemas radiculares excisados (Eliasson, 1971b).

Em raizes gemiferas de alfafa (Medicago sativa $\times M$. falcata), as reservas de amido estavam confinadas na feloderme e nas células do parênquima do xilema e floema (Murray, 1957). Na espécie invasora Euphorbia esula, a ocorrência de amido foi constatada, principalmente, nas células parenquimáticas do estelo, além de estar presente no látex da planta (Bakshi \& Coupland, 1959), enquanto que um baixo conteúdo de amido foi observado no parênquima cortical das raizes de Linaria vulgaris (Bakshi \& Coupland, 1960).

Espécies do cerrado apresentam sistemas subterrâneos, complexos ou não, capazes de armazenar os compostos de reservas. Em 17 espécies nativas, Figueiredo-Ribeiro et al. (1986) verificaram que os carboidratos solúveis eram os principais constituintes dos órgãos subterrâneos. Em Mandevilla velutina, a raiz tuberosa funciona como um órgão de reserva de carboidratos solúveis (Figueiredo-Ribeiro et al., 1986), estando esta característica associada à sua capacidade gemífera (Appezzato-da-Glória \& Estelita, 1995). Paviani \& Magalhães (1996) verificaram que, na raiz horizontal e superficial de Casearia sylvestris, excetuando-se os elementos de vaso, todos os demais elementos do xilema, o parênquima do floema e o córtex armazenavam grãos de amido. Bell et al. (1996) constataram que a reserva de amido nas raizes das Epacridaceae, em resposta ao fogo, estava confinada ao parênquima radial e axial, além de apresentarem reserva de amido na região cortical da raiz.

Trabalhos relacionando o conteúdo dos compostos de reserva dos sistemas radiculares com a iniciação de gemas têm sido realizados. Bowen \& Pate (1993) relataram que as concentrações de amido no córtex das raízes de Stirlingia latifolia declinaram acentuadamente nos primeiros meses, após a ocorrência de fogo, coincidindo com a produção dos brotos radiculares. Os xilopódios de Ocimum nudicaule apresentaram um aumento de carboidratos 
solúveis durante o período de dormência, sendo que este conteúdo diminuiu após a brotação das gemas, com os niveis de enzimas hidrolíticas variando de acordo com os ciclos estacionais da planta e com o conteúdo de carboidratos (Figueiredo-Ribeiro \& Dietrich, 1981; Dietrich \& Figueiredo-Ribeiro, 1985).

\subsection{Estacas radiculares}

A formação de gemas em raizes torna possivel a propagação de plantas por estacas radiculares, sendo um importante meio de reprodução utilizado pelas espécies invasoras (Esau, 1965).

A propagação por estacas radiculares é uma técnica em que as raízes da planta são fragmentadas em pedaços individuais, sendo que cada um destes é capaz de desenvolver gemas e raizes adventícias e, portanto, de regenerar plantas inteiras (MacDonald, 1993). O uso de estacas radiculares é limitado às plantas que possuem a capacidade de produzir brotos ou primórdios de brotos em suas raizes, os quais podem desenvolver-se de gemas dormentes ou de gemas formadas após a estaca radicular ter sido coletada (Mahlsted \& Harber, 1957). Muitas plantas propagadas com sucesso a partir de estacas radiculares pertencem às familias Bignoniaceae, Fabaceae (Leguminosae) e Rosaceae (MacDonald, 1993).

Em geral, as estacas radiculares são mais aptas a produzir brotos do que raizes adventícias (Mahlsted \& Harber, 1957), com os brotos formando-se na extremidade proximal e as raizes na extremidade distal, devido ao fenômeno da polaridade (Hartmann et al., 1990), como observado em Diodia virginiana (Baird et al., 1992). Quando gemas de Rubus idaeus se originam ao longo da estaca, há uma tendência de uma ou mais gemas, próximas a extremidade proximal, se desenvolverem em brotos. Se uma das gemas, independente de sua localização, for mais desenvolvida que as outras, esta será mais apta a se 
transformar em broto e, portanto, brotos podem crescer nas posições mediana e distal das estacas (Hudson, 1954).

Freqüentemente, primeiro ocorre a formação do broto adventício e, posteriormente, das raizes, as quais poderão ser emitidas pelo novo caule ou pela própria estaca (Browse, 1979; Hartmann et al., 1990). Em determinadas plantas, o sistema radicular forma-se simultaneamente ao aparecimento dos primeiros brotos. Em outras plantas, as estacas formam o broto, mas não desenvolvem raízes, ou vice-versa, ocasionando a morte do fragmento radicular (Hartmann et al., 1990).

Algumas espécies regeneram prontamente de estacas radiculares em qualquer época do ano, enquanto outras espécies apresentam uma flutuação sazonal bem marcante na capacidade de desenvolver gemas radiculares (Browse, 1979; Dirr \& Heuser, 1987; Hudson, 1953, 1954, 1955; MacDonald, 1993; Sterrett et al., 1968).

Estacas feitas de raízes de árvores jovens, localizadas próximas do tronco principal, são bem mais sucedidas do que aquelas feitas de raízes de árvores mais velhas, localizadas mais distalmente (Dirr \& Heuser, 1987; Hartmann et al., 1990). O fracasso da regeneração das estacas provenientes de árvores mais velhas é uma decorrência da inabilidade dos fragmentos radiculares para formar um novo sistema radicular, que provavelmente está relacionada ao fenômeno da juvenilidade (Hartmann et al., 1990).

Em Rubus idaeus, as gemas aparecem em intervalos irregulares ao longo de toda a estaca radicular e, embora a maioria das gemas não cresça, suas chances de se desenvolver em brotos parecem ser iguais, qualquer que seja sua orientação (Hudson, 1954). 


\subsection{Fatores de indução}

A expansão vegetativa de um indivíduo pode não ser regular, mas episódica e associada às flutuações dos fatores ambientais e dos ciclos de perturbações (Lacey \& Johnston, 1990).

A iniciação de gemas em raizes está adaptada aos ambientes hostis (Peterson \& Thomas, 1971; Rizzini \& Heringer, 1966; Saner et al., 1995), sendo que vários fatores podem estar envolvidos na indução das gemas radiculares. Estímulos como a remoção da parte aérea, lesão da raiz, exposição à luz ou aumento de temperatura do solo são capazes de induzir a formação de novos brotos nos sistemas radiculares (Lacey \& Johnston, 1990).

\subsubsection{Efeito do fogo}

De modo geral, as árvores atingidas pelo fogo, durante as queimadas, se recuperam através do desenvolvimento de brotos provenientes de gemas endógenas do tronco principal ou de seus ramos. Entretanto, se o tronco caulinar for morto devido a alta intensidade do fogo, novas brotações podem se desenvolver a partir de gemas iniciadas nos sistemas subterrâneos, como em lignotúbers, rizomas e raizes (Lacey \& Jonhston, 1990).

Temperaturas atingidas durante as queimadas têm sido registradas em florestas tropicais. Ewel et al. (1981) constataram temperaturas superiores a $620^{\circ} \mathrm{C}$ na superfície do solo, mas raramente superiores a $100^{\circ} \mathrm{C}$ a $1 \mathrm{~cm}$ ou $50^{\circ}$ C a $2 \mathrm{~cm}$ de profundidade, em uma área de floresta da Costa Rica, após o corte da vegetação. Uhl et al. (1981), medindo a temperatura durante a queimada de áreas florestais da Amazônia, após o corte das árvores, registraram médias de temperaturas máximas de $392^{\circ} \mathrm{C}$ a $7,5 \mathrm{~cm}$ acima do nivel do solo, $138^{\circ} \mathrm{C}$ na superfície do solo e $100^{\circ} \mathrm{C}$ a $1 \mathrm{~cm}$ de profundidade. Num trabalho subsequente, Uhl (1982) verificou que, após um fragmento 
florestal da Amazônia ter sido cortado e queimado, com as temperaturas do fogo atingindo $593^{\circ} \mathrm{C}$ a $10 \mathrm{~cm}$ acima do nivel do solo e $173^{\circ} \mathrm{C}$ a $1 \mathrm{~cm}$ de profundidade, os brotos pós-fogo originaram-se, principalmente, de sistemas subterrâneos visto que, provavelmente, o solo isolou estes sistemas, tornandoos menos expostos durante as queimadas. Em espécies arbóreas e arbustivas de florestas semideciduas brasileiras, logo após a ocorrência de fogo, Castellani (1986), Matthes (1992) e Rodrigues et al. (1990) observaram que estas espécies regeneravam através do desenvolvimento de brotos em sistemas radiculares. Kauffman (1991) também observou que, como resposta a ação do fogo em uma área de floresta tropical, $80 \%$ das 25 famílias de espécies arbóreas estudadas brotaram a partir de sistemas subterrâneos e epicórmicos. Segundo o autor, as três familias mais comuns, Lecythidaceae, Leguminosae e Sapotaceae, apresentaram 100, 68 e 63\% de brotações, respectivamente. Aproximadamente $50 \%$ das espécies de Lecythidaceae e Sapotaceae e $78 \%$ das espécies de Leguminosae formaram brotos provenientes de sistemas subterrâneos.

Em condições de ambientes savânicos, espécies do cerrado brasileiro, como Piptocarpha rotundifolia (Achutti, 1978), Cochlospermum regium (Kirizawa, 1981), Brasilia sickii (Paviani, 1987), Mandevilla illustris e M. vellutina (Appezzato-da-Glória \& Estelita, 1995) e Casearia sylvestris (Paviani \& Magalhães, 1996), também apresentaram a capacidade de formar gemas adventicias nos diferentes tipos de sistemas radiculares. Por exemplo, em Mandevilla illustris e M. velutina, Appezzato-da-Glória \& Estelita (1995) verificaram que as gemas originavam em raizes tuberosas, enquanto que Casearia sylvestris desenvolveu gemas em raizes horizontais e superficiais (Paviani \& Magalhães, 1996).

Deste modo, em regiões sujeitas a ação de fogos periódicos ou de outros tipos de distúrbios, o desenvolvimento de brotos a partir de sistemas 
subterrâneos é uma característica vantajosa ao promover o rápido restabelecimento da cobertura vegetal (Lacey \& Johnston, 1990; Uhl, 1982).

\subsubsection{Lesão ou injúria do sistema radicular}

Muitas plantas lenhosas formam caules a partir de gemas adventícias originadas em raízes, sendo que em algumas espécies, as gemas adventícias formam-se em raízes de plantas intactas (Hartmann et al., 1990). Árvores vigorosas de Liquidambar styraciflua, sem qualquer injúria aparente, liberam da dormência, em anos sucessivos, numerosas gemas radiculares que se desenvolvem em brotos (Brown, 1974). Em condições naturais, Mandevilla velutina e $M$. illustris produzem, esporadicamente, novos brotos a partir da raiz tuberosa. Para testar se raízes não injuriadas são capazes de formar gemas, Peterson \& Thomas (1971) cultivaram plantas de Hieracium florentinum sob condições estéreis e verificaram que gemas formaram-se simultaneamente em diversas raízes. Por outro lado, em muitas plantas, gemas radiculares se formam somente se a raiz for injuriada, com as gemas se diferenciando no tecido caloso formado (Bell, 1993; Lacey \& Johnston, 1990; Priestley \& Swingle, 1929). Em Araucaria cunninghamii (Burrows, 1990), Cochlospermum regium (Kirizawa, 1981) e Piptocarpha rotundifolia (Achutti, 1978), o desenvolvimento de gemas está condicionado às raízes injuriadas.

Se as gemas são formadas num sistema radicular normal, não perturbado, estas são denominadas gemas adicionais. Entretanto, gemas reparativas ocorrem somente após a injúria das raízes (Wittrock, citado por Raju et al., 1966).

Em Linaria vulgaris, a perturbação do solo parece ter um efeito favorável na produção de gemas radiculares, visto que um maior número de gemas foi observado em raízes de solos cultivados do que em raízes de solo não perturbado (Bakshi \& Coupland, 1960). 


\subsubsection{Luz}

Em segmentos radiculares de Linaria vulgaris, a luz aumentou relativamente a taxa de iniciação de gemas (Charlton, 1965; Saner et al., 1995). A exposição à luz das raízes laterais de Liquidambar styraciflua produziram um efeito pronunciado na liberação de gemas dormentes, sendo que o sucessivo desenvolvimento do broto foi determinado pelo grau de competição por água, nutrientes e luz (Brown, 1974).

O fotoperíodo também pode influenciar o desenvolvimento de gemas em raizes em determinadas espécies. Dias curtos promoveram um aumento na produção de gemas em Medicago sativa (alfafa) ao diminuir o crescimento da parte aérea (Carlson, 1965; Carlson et al., 1964). Dias longos favoreceram o crescimento da parte aérea e, portanto, a manutenção da dominância apical, inibindo a iniciação de gemas radiculares em Medicago sativa, Coronilla varia e Rumex acetosella (Carlson, 1965).

\subsubsection{Temperatura}

Temperaturas amenas foram favoráveis à iniciação de gemas radiculares em Chondrilla juncea (Kefford \& Caso, 1972), Diodia virginiana (Baird et al., 1992), Medicago sativa (Carlson et al., 1964) e Robinia pseudoacacia (Sterrett et al., 1968). Entretanto, estacas radiculares de Diodia virginiana formaram gemas após exposição a $0^{\circ} \mathrm{C}$ por até 8 horas e a $-5^{\circ} \mathrm{C}$ por uma hora (Baird et al., 1992).

Em raízes de Pediomelum subacaule, Baskin \& Baskin (1990) verificaram que, embora as gemas sejam ativadas na primavera, atravessam o verão com baixos niveis de desenvolvimento, provavelmente devido as altas temperaturas, e somente no outono encontram condições adequadas de umidade e temperatura. 


\subsubsection{Variação sazonal}

A variação sazonal na capacidade de formação de gemas em raízes tem sido observada em várias espécies (Browse, 1979; Dirr \& Heuser, 1987; Eliasson, 1961, 1971a; Hudson, 1953, 1954, 1955; MacDonald, 1993; Mahlsted \& Harber, 1957; Schier, 1973b), podendo estar relacionada à quantidade de auxina endógena presente nas raízes (Schier, 1973b).

\subsubsection{Profundidade das raizes}

De um modo geral, as gemas são formadas em raízes horizontais localizadas próximas a superfície do solo (Greig \& Mauseth, 1991; Nadeau e Vanden Born, 1989; Paviani \& Magalhães, 1996; Raju et al., 1966; Wilson, 1927) ou em estacas radiculares plantadas superficialmente (Baird et al., 1992).

Entretanto, o sistema radicular de Euphorbia esula, uma herbácea invasora, é capaz de formar gemas em profundidades consideráveis, que variam de 0,3 a 1,8 m (Coupland \& Alex, 1955; Coupland et al., 1955).

\subsubsection{Comprimento da estaca radicular}

O tamanho de uma estaca depende da sua capacidade de armazenar compostos de reserva, os quais são responsáveis pela manutenção da própria estaca e também pela iniciação do processo de regeneração (Browse, 1979). Deste modo, o tamanho da estaca radicular é variável entre as espécies. Segmentos radiculares muito curtos de Convolvulus arvensis foram induzidos a formar gemas pela aplicação de hormônios (Bonnett \& Torrey, 1965). 


\subsubsection{Efeito dos reguladores de crescimento}

Segundo Lacey \& Johnston (1990), 'woody clumps' são formados como um resultado da perda da dominância apical do caule primário, podendo ser uma característica geneticamente determinada ou uma conseqüência da morte, debilitação ou danos físicos do caule principal adulto. A perda da dominância apical favorece o desenvolvimento de gemas suprimidas em caules aéreos, sendo que estas gemas podem brotar simultânea ou intermitentemente.

As gemas de plantas perenes lenhosas automaticamente se liberam da dominância apical quando a parte aérea sofre algum tipo de distúrbio, como corte, queimadas, anelamento ou desfolhamento (Lacey \& Jonhston, 1990). Entretanto, Sandberg (1951) afirma que as raizes de Populus tremuloides devem ser capazes de formar brotos uma vez que estejam vivas, mas certamente esta capacidade é aumentada após o corte da parte aérea ou a separação da raiz do sistema radicular da planta-mãe. Em muitos casos em que raizes laterais de Liquidambar styraciflua são aneladas, gemas são liberadas da dormência no lado distal do sistema radicular (Brown, 1974).

Vários autores concordam que o mecanismo fisiológico que controla 0 brotamento radicular está relacionado ao fenômeno da dominância apical (Eliasson, 1961, 1969, 1971a,b, Farmer, 1962; Lacey \& Johnston, 1990).

Segundo Farmer (1962), em espécies de Populus, a interrupção do movimento basípeto da auxina pelo anelamento do caule ou da raiz ou pelo seccionamento da raiz estimulou a formação de brotos radiculares.

Dentre os reguladores de crescimento, os efeitos das auxinas e citocininas têm sido mais estudados na iniciação e desenvolvimento de gemas radiculares. Carlson (1965) sugere que os reguladores de crescimento provenientes da parte aérea (auxinas) e raízes (citocininas) interagem no controle da iniciação de gemas em raízes. 
Geralmente, as auxinas possuem um efeito inibitório na formação de gemas em raizes (Eliasson, 1961, 1969, 1971a,b; Farmer, 1962; Kefford \& Caso, 1972; MacDonald, 1993; Peterson, 1975; Schier, 1973b). Em alguns casos, a aplicação de baixas concentrações de auxina podem ser estimulantes na iniciação de gemas (Kefford \& Caso, 1972). O desfolhamento intermitente ou contínuo de Medicago sativa promoveu uma redução no número de gemas nos sistemas radiculares. Os efeitos da remoção de folhas jovens pode ter diminuído a fonte de auxina, sugerindo o envolvimento desse hormônio na produção de gemas nas raizes (Carlson et al., 1964). Entretanto, na maioria dos casos, o desenvolvimento de brotos em raizes é inibido pela auxina translocada da parte aérea para o sistema radicular (Eliasson, 1969, 1971a,b; Farmer, 1962). A auxina atinge altos niveis durante o periodo de crescimento ativo da parte aérea (Eliasson 1969, 1971a; Schier 1973b), sendo que esses valores diminuem quando as árvores tornam-se dormentes. Tratamentos realizados para reduzir o nivel de auxina nas raízes, como a remoção do ápice e das gemas axilares, a paralisação do crescimento da parte aérea por tratamento de dias curtos (Eliasson, 1971b), o anelamento do caule ou da raiz e o seccionamento da raiz em relação ao tronco principal (Farmer, 1962), levaram a formação de brotos em raizes. Em estacas radiculares, embora haja a inativação da maior parte da auxina antes disponivel, ainda pode restar uma quantidade suficiente capaz de afetar a iniciação e o desenvolvimento da gema. Desse modo, a inativação da auxina promove uma alteração na concentração hormonal, modificando o estado de inibição completa na planta intacta para inibição parcial na estaca (Schier, 1973b).

Em relação às citocininas, é difícil afirmar se estes hormônios influenciam diretamente na iniciação de gemas ou somente induzem a produção de um tecido caloso no qual se formam as gemas (Peterson, 1975).

A aplicação de citocininas pode ter vários efeitos na formação de gemas em segmentos radiculares. Geralmente, em estacas radiculares, as citocininas 
promovem a formação de brotos, mas podem inibir o desenvolvimento da raizes (Kefford \& Caso, 1972; MacDonald, 1993). Entretanto, em algumas espécies não houve efeito das citocininas no número de gemas (Charlton, 1965). Além dos efeitos esperados, em estacas de Chondrilla juncea, a cinetina também neutralizou a inibição causada pela auxina no desenvolvimento das gemas e alterou a polaridade da formação de gemas ao longo das estacas, de proximal para distal (Kefford \& Caso, 1972). Em Mandevilla illustris, a maior capacidade de tuberização e o número elevado de nódulos vasculares capazes de formar gemas são processos que podem ser induzidos pelas citocininas (Appezzato-da-Glória \& Estelita, 1995). 


\section{MATERIAL E MÉTODOS}

\subsection{Caracterização das áreas de estudo}

O levantamento das espécies que apresentaram brotos a partir de sistemas subterrâneos superficiais foi realizado na mata Santa Elisa (Figura 1), localizada no Centro Experimental de Campinas (CEC) do Instituto Agronômico (IAC), municipio de Campinas, Estado de São Paulo, entre as coordenadas de $22^{\circ} 55^{\prime} \mathrm{S}$ e $47^{\circ} 05^{\prime} \mathrm{W}$, a uma altitude média de $660 \mathrm{~m}$. Este fragmento florestal ocupa uma área total de aproximadamente $10 \mathrm{ha}$, sendo caracterizado como floresta mesófila semidecídua, com árvores do estrato superior alcançando 15 a $20 \mathrm{~m}$ de altura e algumas emergentes atingindo 30-35 m de altura (Rodrigues et al., 1990).

No decorrer dos anos, a mata vem sofrendo inúmeras alterações em sua fisionomia, principalmente pela ação das queimadas, devido a sua proximidade a conjuntos habitacionais. Os incêndios mais recentes ocorreram em 1983, 1985, 1988 (Rodrigues et al, 1990) e 1994 e, de acordo com Matthes', neste último incêndio, uma área de aproximadamente 6 ha foi atingida pelo fogo, resistindo somente algumas espécies arbóreas de grande porte. Atualmente, esta área da mata encontra-se em processo de regeneração através da propagação vegetativa, de propágulos provenientes de outras áreas ou do

\footnotetext{
${ }^{1}$ MATTHES, L.A.F. Comunicação pessoal, 1995.
} 
próprio banco de sementes. Dentro dos limites destes 6 ha queimados, uma área de $4000 \mathrm{~m}^{2}$ foi selecionada para o estudo, sendo subdividida em 40 parcelas de $10 \times 10 \mathrm{~m}$. Em cada parcela, os sistemas subterrâneos das espécies arbóreas e arbustivas foram escavados, visando detectar os pontos de inserção dos brotos nas raizes das plantas-mães.

Com a finalidade de verificar os possiveis fatores de indução na formação de gemas nos sistemas subterrâneos, foi escolhida uma área floristicamente semelhante à mata Santa Elisa, porém não atingida pelo fogo. $A$ área selecionada pertence à Reserva Florestal de Santa Genebra da Fundação Municipal José Pedro de Oliveira (Figura 2), localizada no municipio de Campinas, Estado de São Paulo, entre as coordenadas $22^{\circ} 49^{\prime} S$ e $47^{\circ} 06^{\prime} \mathrm{W}$, com altitudes variando de 580 a $610 \mathrm{~m}$. A Reserva possui uma área total de aproximadamente 252 ha (Matthes, 1992), sendo também caracterizada como floresta mesófila semidecidua.

\subsection{Material botânico}

$\mathrm{Na}$ mata Santa Elisa, coletou-se material vegetal das 8 espécies arbóreas e arbustivas que apresentaram sistemas subterrâneos gemiferos: Bauhinia forficata Link (Caesalpiniaceae); Centrolobium tomentosum Guill. ex Benth. (Fabaceae); Esenbeckia febrifuga (St. Hil.) Juss. ex Mart. (Rutaceae); Inga fagifolia Willd. (Mimosaceae); Lonchocarpus cultratus (Vell.) A.M.G. Azevedo \& H.C. Lima (Fabaceae); Machaerium stipitatum (D.C.) Vog. (Fabaceae); Mollinedia schottiana (Spreng.) Perk. (Monimiaceae) e Polygala klotzschii Chad. (Polygalaceae). O material botânico foi identificado por especialista e as exsicatas encontram-se depositadas no herbário da Universidade Estadual de Campinas (UEC), sob os números 35772 (C. tomentosum), 35774 (M. schottiana), 35776 (M. stipitatum), 35777 (E. 
febrifuga), 35778 (B. forficata), 35780 (L. cultratus), 35781 (I. fagifolia) e 35785 (P. klotzschii).

\subsection{Coleta do material}

Foram coletados, na mata Santa Elisa, fragmentos radiculares para as análises anatômicas, microquímicas e ultra-estruturais. Também foram coletados segmentos radiculares para a confecção de estacas das duas espécies mais representativas do levantamento supracitado, C. tomentosum e M. stipitatum, na mata Santa Elisa e na área da Reserva Florestal de Santa Genebra.

\subsection{Estudos anatômicos}

A análise anatômica foi realizada mediante coleta e fixação em FAA 50 (Sass, 1951) dos sistemas subterrâneos gemiferos. Materiais mais rígidos foram transferidos para uma solução de álcool etílico $96^{\circ}$, água destilada e glicerina (1:1:1). As secções transversais feitas à mão-livre e em micrótomo de deslize (60 $\mu \mathrm{m}$ de espessura) foram clarificadas com hipoclorito de sódio a $20 \%$, lavadas com água destilada, coradas com Azul de Astra e Safranina aquosa (Gerlach, 1969), desidratadas em série alcoólica-etílica, acetato de butila 50 e 100\% e montadas em resina sintética "Entellan".

O estudo anatômico para determinar a origem das gemas foi realizado de acordo com a disponibilidade de material botânico. Desta forma, as espécies $M$. stipitatum e $M$. schottiana foram analisadas a partir de raizes obtidas no campo. Também foram estudadas gemas de $C$. tomentosum e $M$. stipitatum obtidas a partir do experimento de estacas radiculares (item 3.9). As amostras foram coletadas e fixadas em FAA 50 (Sass, 1951) ou em solução de Karnovsky (Karnovsky, 1965). Para melhor fixação, as amostras foram levadas 
a uma bomba de vácuo para a retirada do ar contido nos espaços intercelulares. As amostras fixadas em FAA 50 foram desidratadas em série alcoólica-etílica, infiltradas e incluídas em parafina, seccionadas transversalmente (11 a $13 \mu \mathrm{m}$ de espessura), distendidas em lâminas (Sass, 1951), coradas com Azul de Astra e Fucsina Básica (Roeser, 1972) e montadas em resina sintética "Entellan". As amostras fixadas em solução de Karnovsky foram desidratadas através da série alcoólica-etílica, infiltradas com a resina glicol metacrilato da Reichert-Jung, seccionadas transversalmente a $5 \mu \mathrm{m}$ de espessura, coradas com azul de toluidina 0,05\% em tampão fosfato e ácido cítrico (Sakai, 1973) ou com Azul de Astra e Fucsina Básica (Alves de Brito \& Alquini, 1996) e montadas em resina sintética "Entellan".

As fotomicrografias dos materiais preparados em lâminas foram feitas em fotomicroscópio NIKON AFX-DX, com as escalas micrométricas fotografadas e ampliadas nas mesmas condições ópticas utilizadas.

\subsection{Testes microquimicos}

Os testes microquímicos foram realizados utilizando-se seç̧ões de material não fixado dos sistemas subterrâneos das oito espécies levantadas. As secções foram feitas à mão-livre com auxílio de lâmina de barbear ou em micrótomo de deslize. A presença de compostos fenólicos foi evidenciada pelo cloreto férrico (Johansen, 1940); o amido foi identificado pelo emprego de cloreto de zinco iodado (Strasburger, 1913); as substâncias graxas pelo Sudan IV (Jensen, 1962); as proteínas totais por "Aniline blue black" (Fisher, 1968) e os polissacarídeos pelo vermelho de rutênio (Johansen, 1940). 


\subsection{Análises ultra-estruturais}

Fragmentos dos sistemas subterrâneos providos de gemas das espécies $M$. stipitatum (estacas radiculares) e $M$. schottiana (raízes obtidas no campo) foram analisados ao microscópio eletrônico de varredura. As amostras foram fixadas em solução de Karnovsky (Karnovsky, 1965) e levadas a uma bomba de vácuo para a remoção do ar contido nos espaços intercelulares. Posteriormente, procedeu-se a desidratação das amostras em série alcoólicaetílica até álcool absoluto e, em seguida, passagem pelo ponto crítico de $\mathrm{CO}_{2}$ (Horridge \& Tamm, 1969), montagem sobre suportes de alumínio e recobrimento com uma camada de ouro de 30 a $40 \mathrm{~nm}$. As análises e as eletromicrografias foram realizadas em microscópio eletrônico de varredura modelo DSM 940A Zeiss, operado a $5 \mathrm{kV}$, com as escalas das eletromicrografias diretamente impressas nas mesmas.

\subsection{Simulação da ação do fogo na indução de gemas}

O experimento de simulação da ação do fogo na indução de gemas, visando verificar o efeito das queimadas, foi realizado em condições de campo na mata Santa Elisa (Figuras 3-6). Cinco raízes de diferentes indivíduos das duas espécies mais representativas do levantamento anteriormente citado, $C$. tomentosum e M. stipitatum, foram selecionadas e escavadas. Segmentos radiculares de aproximadamente $1 \mathrm{~m}$ de comprimento foram expostos e, em seguida, recobertos com bagacilho de cana $(1,5-2,0 \mathrm{~cm}$ de altura $\times 20 \mathrm{~cm}$ de largura), a fim de padronizar e simular a serrapilheira presente na mata. A extremidade de um termopar de cobre-constantan foi colocada junto à superfície da raiz enquanto a outra extremidade foi conectada a um coletor e armazenador de dados modelo CR7X (Campbell Sci./USA), visando medir a temperatura da superfície externa do sistema radicular durante a queimada. As 
leituras foram obtidas em intervalos de $7 \mathrm{~s}$ durante aproximadamente $180 \mathrm{~s}$, tempo necessário para a queima do bagacilho.

\subsection{Simulação da injúria mecânica na indução de gemas}

A injúria mecânica do sistema radicular foi realizada através da retirada parcial da casca, a qual é definida como um conjunto de tecidos, situado externamente ao câmbio vascular, presente em plantas com crescimento secundário (Instituto Florestal, 1996). A retirada parcial da casca foi realizada em cinco raízes de diferentes individuos de $C$. tomentosum e $M$. stipitatum, na mata Santa Elisa e na mata da Reserva Florestal de Santa Genebra. Segmentos de raízes de aproximadamente $1 \mathrm{~m}$ de comprimento foram expostos com o auxílio de pás e enxadas. A seguir, com um canivete de enxertia, fragmentos da casca na porção superior da raiz foram retirados, mantendo-se um espaçamento de cerca de $10 \mathrm{~cm}$ entre os ferimentos (Figuras 7-8).

\subsection{Estacas radiculares}

Segmentos de sistemas radiculares das espécies $C$. tomentosum e $M$. stipitatum foram coletados na mata Santa Elisa e na mata da Reserva Florestal de Santa Genebra, a fim de verificar a capacidade gemífera de estacas radiculares de áreas perturbada e não perturbada pela ação do fogo. As raízes

foram escavadas com o auxílio de pás e enxadas, lavadas em água corrente e segmentadas em estacas. Dez estacas radiculares com aproximadamente 20 $\mathrm{cm}$ de comprimento e $1 \mathrm{~cm}$ de diâmetro foram plantadas horizontalmente em caixas plásticas, contendo areia como substrato, em casa de vegetação. 


\section{RESULTADOS}

\subsection{Estudos anatômicos, microquimicos e ultra-estruturais}

O estudo anatômico dos sistemas subterrâneos superficiais gemíferos (Figuras 9-14) das oito espécies arbóreas e arbustivas confirma a natureza radicular dos mesmos, visto que o xilema primário do cilindro vascular apresenta maturação centrípeta (xilema exarco) (Figuras 15-22).

A descrição das raizes gemiferas, apresentada a seguir, refere-se ao número de pólos de xilema primário, ao tipo de estelo e à ocorrência de compostos fenólicos e de reserva.

A raiz de $B$. forficata é tetrarca e protostélica (Figura 15); células do parênquima axial e radial do xilema e floema secundários contendo, predominantemente, amido (Figuras 23 e 24) e algumas células com substâncias graxas e compostos fenólicos. Em C. tomentosum, a raiz é hexarca e protostélica (Figura 16); possui amido e substâncias graxas no parênquima axial e radial do xilema e do floema secundários e, em menor proporção, compostos fenólicos no parênquima axial e radial do floema secundário. E. febrifuga possui raiz diarca e protostélica (Figura 17); substâncias graxas e amido no parênquima axial e radial do xilema e do floema secundários. I. fagifolia apresenta raiz heptarca e sifonostélica (Figura 18); amido, substâncias graxas e compostos fenólicos no parênquima axial e radial do xilema e floema secundários. A raiz de $L$. cultratus é tetrarca e protostélica (Figura 19); células do parênquima axial e radial do floema e xilema 
secundários apresentando substâncias graxas. $M$. stipitatum possui raiz pentarca e protostélica (Figura 20); as células do parênquima axial e radial do xilema e do floema secundários apresentam, predominantemente, amido e, em menor proporção, substâncias graxas. M. schottiana possui raiz tetrarca e protostélica (Figura 21); as células do parênquima radial e axial do xilema e floema secundários apresentam amido e substâncias graxas; algumas células, principalmente as do parênquima radial, também possuem compostos fenólicos. P. klotzschii possui raiz pentarca e protostélica (Figura 22); células do parênquima axial e radial do xilema e floema secundários e do parênquima cortical apresentam substâncias graxas (Figuras 25 e 26); células do parênquima radial do xilema também apresentam amido, em menor proporção.

As gemas radiculares adventicias de $M$. schottiana (Figuras 27-30) formam-se assincronicamente, ou seja, brotações jovens providas de gemas axilares (Figura 27) aparecem lado a lado de gemas no início do desenvolvimento na superfície da raiz (Figura 29). O estudo anatômico revela que estas gemas originam-se nas proximidades do câmbio vascular (Figura 30). A diferenciação vascular do xilema primário na região de conexão entre a raiz e a gema ocorre acropetamente, evidenciando a origem endógena da mesma.

Em M. stipitatum, a estrutura anatômica das raizes gemiferas coletadas no campo, no setor em que ocorre a diferenciação das gemas radiculares, apresenta uma proliferação parenquimática entre o cilindro vascular e a periderme de tal forma que, neste setor, o floema secundário torna-se interrompido (Figura 31). As gemas originam-se a partir de meristemóides localizados perifericamente nesta proliferação (Figura 31, seta) e, portanto, abaixo da periderme. Durante o desenvolvimento das gemas, ocorre a conexão vascular destas com a raiz-mãe através da diferenciação acrópeta e basípeta de elementos vasculares. As gemas, providas de vários primórdios foliares, tornam-se visiveis na superfície da raiz-mãe após o rompimento da periderme 
(Figuras 32 e 33). As análises anatômicas (Figuras 36-41) das gemas formadas a partir das estacas radiculares permitiram observar que o processo de formação das gemas adventícias obedece o mesmo padrão daquelas obtidas de raizes gemíferas coletadas no campo, ou seja, ocorre sempre a proliferação parenquimática anterior a diferenciação das gemas (Figuras 34 e 35, 47 e 48). Através das análises anatômicas das estacas radiculares gemíferas (Figuras 34-37), foi possivel observar que parte da proliferação celular que leva à interrupção do tecido floemático no setor de diferenciação das gemas, resulta da atividade do câmbio vascular (Figuras 34 e 35). Similarmente ao que ocorre no campo, as gemas originam-se na periferia desta proliferação (Figuras 36 e 37) e, com o desenvolvimento, estabelecem a conexão vascular com a raizmãe através da diferenciação acrópeta e basípeta dos tecidos vasculares (Figura 37). Como algumas raizes laterais da estaca também apresentam gemas, e estas raizes possuem diâmetro inferior ao da raiz de origem (Figura 56), foi possivel observar todos os tecidos envolvidos na proliferação celular. A estrutura anatômica da raiz lateral, no setor desprovido de gemas (Figura 38), caracteriza-se pela presença da periderme abaixo da qual encontram-se duas ou três camadas de células parenquimáticas derivadas do periciclo. Sob o floema primário lignificado ocorrem o floema secundário, o câmbio vascular, o xilema secundário e o xilema primário. Comparando-se a estrutura anatômica das raizes laterais das estacas nos setores desprovido (Figura 38) e provido de gemas (Figuras 39-41), foi possivel observar que a proliferação parenquimática responsável pela iniciação das gemas adventícias é resultante de divisões das células do periciclo, do parênquima radial floemático e do câmbio vascular. A diferenciação de uma destas gemas a partir de áreas meristemáticas periféricas desta proliferação pode ser vista na Figura 39. Com o desenvolvimento, as gemas formadas assincronicamente emergem para a superfície radicular após o rompimento da periderme (Figuras 42-46). 
Em C. tomentosum, as gemas radiculares sempre se formam na porção proximal da estaca radicular (Figura 58), a qual desenvolve um tecido caloso conspícuo que resulta num aumento do diâmetro da estaca nessa região (Figura 59). O tecido do calo caracteriza-se por apresentar células de aspecto parenquimático, sendo formado pela atividade do câmbio vascular, provavelmente em resposta ao ferimento causado durante a confecção da estaca. Nesta espécie, as gemas originam-se endogenamente nas proximidades do câmbio vascular e, portanto, não estão associadas diretamente ao tecido do calo (Figuras 49-52). A conexão vascular da gema ao estelo da raiz ocorre acropetamente (Figura 50). Com o desenvolvimento, as gemas e seus respectivos primórdios foliares pressionam os tecidos externos à área de iniciação, formando uma cavidade entre os primórdios foliares e as células circundantes colapsadas (Figura 51). As gemas emergem na superfície da estaca através do rompimento dos tecidos periféricos (Figura 52).

\subsection{Simulação da ação do fogo na indução de gemas}

No experimento da simulação de queimada, a superfície externa das raizes de $C$. tomentosum e $M$. stipitatum, submetidas a ação do fogo, atingiram uma temperatura média de $54^{\circ} \mathrm{C}$. A variação da temperatura, durante o período da queima do bagacilho de cana (180 s), pode ser observada na Figura 53. Gemas radiculares não se formaram durante os doze meses que se seguiram à instalação do experimento.

\subsection{Simulação da injúria mecânica na indução de gemas}

O acompanhamento no campo, durante os doze meses que se seguiram à retirada parcial da casca das raízes de $C$. tomentosum e $M$. stipitatum, em ambas as áreas de estudo, permitiu observar que as áreas lesadas 
apresentavam os tecidos escurecidos pela oxidação, não havendo qualquer tipo de proliferação celular que pudesse levar à formação de um tecido caloso cicatricial ou mesmo à indução de gemas radiculares.

\subsection{Estacas radiculares}

As estacas radiculares de M. stipitatum coletadas em novembro de 1996 , na mata Santa Elisa, e em outubro de 1997, na Reserva Florestal de Santa Genebra, apresentaram semelhante processo de regeneração. As gemas radiculares formaram-se individualmente ou em grupos ao longo da estaca, podendo desenvolver-se ou não nas proximidades de uma raiz lateral ou de sua cicatriz (Figuras 54-56). Desta forma, as gemas distribuíram-se ao acaso, não obedecendo um padrão de desenvolvimento. A figura 57 ilustra a parte aérea proveniente do desenvolvimento de uma gema radicular. Nas estacas coletadas na mata Santa Elisa, as gemas formaram-se por volta de 15 dias, enquanto as gemas das estacas coletadas na Reserva Florestal de Santa Genebra originaram-se aos 60 dias após o plantio. Em geral, mais de uma gema presente na estaca desenvolveu-se em broto.

Por outro lado, as estacas radiculares de $C$. tomentosum coletadas na mata Santa Elisa não apresentaram brotações em 90 dias. Porém, as coletadas na Reserva Florestal de Santa Genebra formaram brotos em 45 dias. Após 34 dias do plantio, a extremidade proximal da estaca aumentou de diâmetro devido ao desenvolvimento de um calo cujas características estão descritas no item 4.2. A formação de uma ou duas gemas ocorreu apenas na região seccionada da extremidade proximal da estaca (Figuras 58 e 59).

As estacas radiculares formaram raízes adventícias, principalmente, após ocorrer o alongamento do eixo caulinar e conseqüente expansão dos primórdios foliares. Em C. tomentosum, estas raízes formaram-se, eventualmente, apenas na extremidade proximal da estaca e em estreita 
associação ao brotamento caulinar. Entretanto, em M. stipitatum, o enraizamento da estaca ocorreu preferencialmente na extremidade distal. 


\section{DISCUSSÃO}

Embora a formação de gemas radiculares em espécies arbóreas de florestas temperadas seja considerada um evento bastante comum e de vital importância na manutençăo e dinâmica destas florestas (Koop, 1987; Jeník, 1994; Raju et al., 1966; Rood et al., 1994), apenas recentemente este fenômeno vem sendo relatado em florestas tropicais brasileiras (Aidar, 1992; Castellani, 1986; Matthes, 1992; Rodrigues et al., 1990). Visto que os órgãos subterrâneos gemiferos podem ter origem radicular, caulinar ou mista, as observações de campo, realizadas pelos referidos autores, seriam insuficientes para confirmar a ocorrência de raizes gemíferas em florestas brasileiras. Neste contexto, as análises anatômicas efetuadas no presente trabalho permitem, pela primeira vez, confirmar a ocorrência deste fenômeno.

Rizzini \& Heringer (1962) descrevem as raizes gemíferas como sendo raizes longas, localizadas paralelamente à superfície do solo e que se caracterizam anatomicamente por apresentarem uma porção central desprovida de uma medula verdadeira e pela presença do xilema primário com maturação centripeta. Nas oito espécies estudadas, as raízes gemíferas são longas e superficiais e apenas em I. fagifolia a raiz apresenta uma pequena medula, sendo que nas demais espécies as raízes são protostélicas. Sandberg (1951) não encontrou nenhuma diferença anatômica em raízes de diferentes porções do sistema radicular de Populus tremuloides que pudesse distinguir certas raízes como estritamente gemíferas. Porém, Greig \& Mauseth (1991) relataram para a espécie arbórea Piper auritum a ocorrência de raizes horizontais que podem atingir até nove metros a partir do ponto de origem, 
formando gemas adventícias ao longo destas. Estas raízes possuem estrutura anatômica diferente das raizes subterrâneas verticais, as quais estão relacionadas à função de absorção. Segundo os autores, a diferença básica entre as raizes subterrâneas verticais e horizontais está no fato de que esta última apresenta floema particularmente abundante, diâmetro da medula bastante reduzido, menor número de pólos de protoxilema e diâmetro dos elementos de vaso proporcionalmente maiores do que as raizes verticais. Os mesmos autores ainda sugerem que estas caracteristicas das raízes subterrâneas horizontais facilitam o transporte de água e nutrientes para os ramos aéreos adventícios surgidos ao longo das mesmas. Embora não tenham sido analisadas, no presente estudo, as diferenças anatômicas entre as raízes gemiferas e não gemíferas, todas têm como características em comum a localização superficial no solo e a presença de reservas constituídas predominantemente por amido. Somente em $P$. klotzschii o material de reserva predominante é constituído por substâncias graxas. Bowen \& Pate (1993) observaram a relação entre as reservas de amido da raiz de Stirlingia latifolia e o desenvolvimento dos brotos. Segundo estes autores, a concentração de amido no córtex radicular declinou acentuadamente nos primeiros meses após o fogo, coincidindo com a produção das gemas radiculares. Bell et al. (1996) apresentaram clara evidência de que certas categorias anatômicas, organográficas e de reserva exibidas por representantes das Epacridaceae estão relacionadas com a estratégia de resposta ao fogo. De acordo com estes autores, as espécies que se reproduzem vegetativamente através de sistemas subterrâneos possuem o sistema radicular bastante ramificado e desenvolvido e elevadas quantidades de reservas de amido. Por outro lado, aquelas produtoras de sementes possuem um sistema radicular menos desenvolvido e - acúmulo de amido é menor, devido ao menor desenvolvimento do parênquima radial do xilema. Casearia sylvestris (Paviani \& Magalhães, 1996) e Mandevilla velutina (Appezzato-da-Glória \& Estelita, 1995), espécies do 
cerrado brasileiro sujeitas a ação do fogo, armazenam considerável proporção de compostos de reserva nas raízes, estando esta característica associada à capacidade gemifera das mesmas. Figueiredo-Ribeiro \& Dietrich (1981) verificaram que os niveis de carboidratos do sistema subterrâneo de Ocimum nudicaule diminuíram acentuadamente com o processo de brotação das gemas e desenvolvimento das porções aéreas da planta. Pelo exposto, os compostos de reserva presentes nas raizes das espécies estudadas poderiam estar disponiveis para o processo de iniciação e desenvolvimento das gemas.

As gemas radiculares das três espécies estudadas apresentam diferentes padrões de desenvolvimento que, de acordo com Peterson (1975), resultam dos diversos tecidos da raiz envolvidos na sua formação. Segundo a classificação dos sítios de iniciação de gemas radiculares estabelecida por este autor, as gemas de $M$. schottiana e $C$. tomentosum, ao se formarem nas proximidades do câmbio vascular, melhor se enquadram no tipo dois, isto é, iniciadas no felogênio e outros tecidos derivados do periciclo. Appezzato-daGlória \& Estelita (1995) também observaram que, em Mandevilla velutina e $M$. illustris, as gemas formaram neste sítio a partir de divisões do câmbio vascular. Embora $C$. tomentosum desenvolva um tecido caloso na extremidade da estaca radicular como resposta ao ferimento ocasionado, este tecido não possui nenhuma relação direta com a iniciação das gemas radiculares nesta espécie. Em estacas de Acanthus montanus, Taylor (1926) também observou que, embora houvesse a formação de um tecido caloso, as gemas se formavam a partir do periciclo. Por outro lado, em Machaerium stipitatum, a iniciação de gemas é precedida pela formação de um tecido caloso a partir da proliferação celular do periciclo, raios parenquimáticos e câmbio vascular. Portanto, o sítio de iniciação das gemas desta espécie, de acordo com a classificação de Peterson (1975), corresponde ao tipo seis, ou seja, as gemas originam-se a partir de um calo radicular. A partir desta massa de tecido caloso são diferenciados os primórdios de gema. Em Ophioglossum vulgatum, Wardlaw 
(1953) verificou que os primórdios de gemas radiculares formaram-se a partir de uma massa meristemática de células resultante da divisão de um grupo de células parenquimáticas corticais. A formação da massa meristemática de células é um processo semelhante ao verificado em $M$. stipitatum. Segundo Kirizawa (1981), a formação de gemas radiculares em Cochlospermum regium provocou uma alteração no câmbio vascular no setor de origem das gemas, ou seja, a partir do parênquima do floema e, às vezes, do parênquima radial desse tecido vascular. Paviani (1987) também verificou que em Brasilia sickii, a gema adventícia forma-se pela desdiferenciação de células localizadas superficialmente em uma área parenquimática resultante do processo de tuberização do xilopódio, que tem origem hipocotiledonar e radicular.

Bonnett \& Torrey (1966) discutem a existência de um primórdio indeterminado capaz de se desenvolver em gema ou raiz lateral. Segundo Bakshi \& Coupland (1959), é muito difícil distinguir um primórdio de gema de um primórdio radicular, iniciados no periciclo, antes de sua emergência da raizmãe. Entretanto, Myers et al. (1964) e Polowick \& Raju (1982) conseguiram identificar tais primórdios nos estágios iniciais do desenvolvimento. As gemas radiculares das três espécies estudadas podem ser distinguidas das raízes laterais antes da sua emergência da raiz-mãe, visto que não se desenvolvem diretamente do periciclo e as gemas já apresentam primórdios foliares ainda no interior da raiz-mãe, assim como verificado em Mandevilla velutina por Appezzato (1988).

Em Centrolobium tomentosum forma-se uma cavidade acima dos primórdios foliares da gema radicular, fato também verificado por Burrows (1990) em Araucaria cunninghamii. O mesmo autor relata que algumas folhas que circundam o meristema parecem se desdiferenciar de células do córtex secundário. Entretanto, nas espécies estudadas, as folhas se desenvolvem a partir do meristema apical da gema. 
De acordo com a classificação das gemas quanto a sua origem proposta por Bell (1993) e Brown (1974), M. schottiana e C. tomentosum formam gemas endogenamente, ao contrário das gemas de $M$. stipitatum, que se originam de forma exógena na raiz a partir de tecidos externos ao estelo. As gemas também podem ser classificadas em adicionais e reparativas, de acordo com Wittrock, citado por Raju et al. (1966). As gemas adicionais são pré-formadas, ou seja, já se encontram presentes nas raizes, necessitando apenas de algum estímulo para o seu desenvolvimento em caules aéreos. Em Populus tremuloides, o critério adotado por Sandberg (1951) para caracterizar uma gema radicular adicional foi baseado na presença de vários anéis de crescimento, depositados ao redor do ponto onde o cordão procambial da gema estabelece a conexão com o câmbio da raiz-mãe. Esta deposição de anéis de crescimento é resultante da continuidade do crescimento secundário da raiz após a formação da gema e, deste modo, esta pode estar mais ou menos embebida pelos anéis de crescimento na época em que for estimulada para se desenvolver em um eixo caulinar. Além disto, segundo o autor, ocorre a formação de irregularidades na superfície da raiz devido à presença de gemas adicionais que formam protuberâncias que não chegam a romper a periderme. Nas três espécies estudadas, as gemas são reparativas pois estas não apresentam deposição de camadas de xilema secundário ao seu redor e quando ocorrem as irregularidades na superfície da raiz, estas são resultantes da emergência das gemas que leva ao rompimento da periderme. Em $P$. tremuloides, Sandberg (1951) questionou se todos ou a maioria dos eixos caulinares se desenvolvem a partir de gemas adicionais presentes nas raízes, antes da planta-mãe ser cortada. Contudo, segundo o autor, os resultados indicaram que, numa mesma estação de crescimento, os brotos formados de gemas adicionais eram menos freqüentes do que os formados de gemas reparativas, além de serem menos aptos a produzirem caules vigorosos. 
Portanto, de acordo com DesRochers ${ }^{2}$, espécies de Populus possuem a capacidade de se regenerar através de gemas pré-formadas (adicionais) ou neoformadas (reparativas) nos sistemas radiculares. Segundo Rizzini \& Heringer (1966), em condições de cerrado, a formação de gemas radiculares em espécies arbóreas é de origem traumática e, portanto, a partir de gemas de natureza reparadora enquanto em subarbustos, as gemas formam-se espontaneamente em raízes íntegras. Em Araucaria cunninghamii, como nas espécies arbóreas do cerrado, a iniciação de gemas não ocorre normalmente e, portanto, gemas pré-formadas não estão presentes na raiz desta espécie (Burrows, 1990).

Segundo Esau (1965), as gemas adventícias geralmente estabelecem sua conexão vascular com a raiz-mãe por diferenciação basípeta do procâmbio. Entretanto, de acordo com a mesma autora, nas gemas que têm origem endógena, por exemplo, no periciclo, a conexão vascular com a raiz é formada por diferenciação acrópeta e nas gemas iniciadas próximas à superfície, portanto, de origem exógena, a diferenciação vascular é basípeta. Em Centrolobium tomentosum e Mollinedia schottiana, a conexão vascular entre a gema e a raiz-mãe ocorre acropetamente, sendo que em Machaerium stipitatum, a diferenciação é acrópeta e basipeta, confirmando as observações de Esau (1965). Wardlaw (1953) também observou que a conexão vascular das gemas de Ophioglossum vulgatum, formadas exogenamente a partir de uma massa meristemática de células, ocorre basipetamente, conectando a gema ao estelo da raiz. Contudo, em Populus tremuloides, apesar das gemas se originarem no periciclo, a conexão vascular ocorre basipetamente (Sandberg, 1951).

Geralmente, a formação e o desenvolvimento de gemas radiculares

²DesROCHERS, A. Comunicação pessoal, 1997. 
estão relacionados aos fatores de perturbação ambiental, que provocam distúrbios na parte aérea ou no sistema radicular da planta (Lacey \& Johnston, 1990). Desse modo, os fatores como a temperatura (Baird et al.; 1992; Baskin \& Baskin, 1990), corte da parte aérea da planta (Farmer, 1962; Paukkonen et al., 1992), injúrias mecânicas na raiz (Baird et al., 1992; Bell, 1993; Burrows, 1990; Rizzini \& Heringer, 1966) e exposição da raiz à luz (Brown, 1974; Carlson et al., 1964; Charlton, 1965; Lacey \& Johnston, 1990) são capazes de induzir a iniciação e o desenvolvimento de gemas radiculares.

No presente trabalho, o levantamento das espécies com raizes gemíferas foi realizado após a mata ter sofrido a ação de uma queimada. 0 questionamento levantado foi se o fogo induziu a iniciação de gemas através da quebra da dominância apical, visto que a parte aérea das espécies estudadas encontrava-se morta ou bastante danificada, ou por elevar a temperatura do sistema radicular.

Em Casearia sylvestris, verificou-se a iniciação de gemas radiculares após a ocorrência de várias queimadas (Paviani \& Magalhães, 1996). Entretanto, neste trabalho, os autores não elucidam o grau do dano causado na planta pela queimada, ou seja, se o fogo afetou somente a parte aérea ou também o sistema radicular. Em Diodia virginiana, a emergência de brotos em estacas radiculares aumentou com a elevação da temperatura, sendo maior a $35^{\circ} \mathrm{C}$ (Baird et al., 1992). Em condições de florestas tropicais, a temperatura do solo a $1 \mathrm{~cm}$ de profundidade pode atingir valores de até $173^{\circ} \mathrm{C}$ (Uhl, 1982). Porém, no presente estudo, a simulação da ação do fogo, em condições de campo, com uma temperatura média de $54^{\circ} \mathrm{C}$ ao nivel da raiz, sugere que o aumento da temperatura do sistema radicular não é, isoladamente, o fator que induz a formação de gemas. Além disto, a injúria causada nos sistemas radiculares através dos ferimentos simulados com a retirada parcial da casca também não foi um fator de indução na iniciação das gemas, assim como a exposição dos sistemas radiculares à luz durante a realização destes 
tratamentos. Em raízes injuriadas de Araucaria cunninghamii, Burrows (1990) verificou a existência de pouca calosidade, sendo que as gemas não se formaram nas áreas injuriadas. Segundo Eliasson (1971b), experimentos com segmentos radiculares com casca injuriada indicaram que ocorre sintese de auxina no tecido danificado a um nível inibitório para o desenvolvimento dos brotos. O fato de que as injúrias ao nivel da raiz, promovidas pelos tratamentos realizados no presente estudo não tenham levado à formação de gemas adventícias sugere que o fogo, ao danificar a parte aérea das plantas, tenha provocado a quebra da dominância apical levando a formação de gemas no sistema radicular. Segundo Uhl (1982), o solo pode isolar o sistema radicular, tornando-o menos exposto durante as queimadas.

Vários trabalhos têm demonstrado que a perturbação do estado fisiológico da árvore (Farmer, 1962; Paukkonen et al., 1992) pode levar à iniciação de gemas nos sistemas radiculares. Em espécies de Populus, segundo DesRochers ${ }^{2}$, a maioria dos brotos radiculares desenvolve-se após um grande distúrbio que quebra a dominância apical do tronco principal. Rodrigues et al. (1990), estudando a mata Santa Elisa após a passagem de fogo, porém numa área diferente da estudada no presente trabalho, verificou a existência de vinte e uma espécies com raízes gemíferas. Destas, cinco espécies são comuns ao levantamento realizado no presente trabalho, pertencentes às famílias Caesalpiniaceae, Fabaceae e Rutaceae. Segundo Kauffman (1991), a regeneração das espécies arbóreas através da formação de brotos a partir de sistemas subterrâneos, após a ocorrência de fogo, tem grande representatividade, ocorrendo em $78 \%$ das espécies de Leguminosae estudadas por ele numa floresta tropical.

Em algumas espécies, gemas radiculares somente se desenvolvem após o caule ser cortado ou quando suas raízes são seccionadas e removidas do efeito da dominância apical (Farmer, 1962; Lacey \& Johnston, 1990; Paukkonen et al., 1992; Schier, 1971a,b). Provavelmente, a auxina produzida 
na parte aérea durante o crescimento ativo desta exerça uma influência inibidora na produção de gemas radiculares (Eliasson, 1969, 1971a; Schier, 1973b; Sterrett et al., 1968). De fato, estacas radiculares de Centrolobium tomentosum e Machaerium stipitatum são capazes de formar gemas adventícias. Possivelmente, a fragmentação das raízes tenha retirado a influência inibidora da dominância apical exercida pela parte aérea (Eliasson, 1971a; Schier, 1973b; Sterrett et al., 1968). A formação de gemas em estacas radiculares, coletadas nas áreas perturbada e não perturbada pela ação do fogo, vem corroborar a idéia de que a regeneração vegetativa de espécies arbóreas, após a ocorrência de incêndios em florestas tropicais, esteja ligada à quebra da dominância apical devido aos danos causados à parte aérea das plantas.

Em condições de campo, as duas espécies exibem várias brotações ao longo de uma mesma raiz superficial. Porém, nas estacas radiculares, C. tomentosum forma gemas somente na extremidade proximal da estaca enquanto as gemas de $M$. stipitatum distribuem-se ao longo de toda a estaca. De acordo com Kerbauy ${ }^{3}$, esta distribuição diferencial das gemas formadas no campo ou em estacas, como a verificada em C. tomentosum, é uma característica intrínseca da própria espécie. O fato das estacas radiculares de C. tomentosum, coletadas na mata Santa Elisa, não terem formado gemas enquanto aquelas coletadas na Reserva Florestal de Santa Genebra formarem, pode ser uma conseqüência das estacas terem sido coletadas de raízes, localizadas distalmente, de árvores velhas (Dirr \& Heuser, 1987; Hartmann et al., 1990).

Schier (1971b) verificou que os brotos radiculares de Populus tremuloides freqüentemente se desenvolvem em grande número, não havendo

\footnotetext{
${ }^{3}$ KERBAUY, G.B. Comunicação pessoal, 1998.
} 
influência inibidora entre eles. Nas espécies estudadas, mais de um broto se desenvolveu na mesma estaca radicular e, em condições de campo, uma seqüência de eixos caulinares pode ser observado ao longo de uma mesma raiz.

A capacidade gemífera das raízes parece ser um mecanismo de adaptação à reprodução vegetativa (Appezzato, 1988; Paviani \& Magalhães, 1996), garantindo a sobrevivência da espécie em resposta às condições adversas do ambiente que desfavorecem a reprodução sexuada. Este tipo de propagação vegetativa possibilita a formação de novos indivíduos próximos à planta-mãe, podendo resultar num padrão de distribuição espacial agregada (Rodrigues et al., 1990), como verificado por Aidar (1992) para a espécie Centrolobium tomentosum. Portanto, a confirmação da existência de raízes gemíferas, associada às características ecológicas das espécies providas destas estruturas, poderia mudar muitos aspectos da discussão sobre a dinâmica de comunidades e dos procedimentos adequados de manejo e recuperação de fragmentos florestais. 


\section{CONCLUSÕES}

- No levantamento realizado no fragmento de floresta mesófila semidecídua, que possui um histórico de perturbação por fogo, foram identificadas oito espécies arbóreas e arbustivas apresentando sistemas subterrâneos superficiais gemiferos: Bauhinia forficata Link, Centrolobium tomentosum Guill. ex Benth., Esenbeckia febrifuga (St. Hil.) Juss. ex Mart., Inga fagifolia Willd., Lonchocarpus cultratus (Vell.) A.M.G. Azevedo \& H.C. Lima, Machaerium stipitatum (D.C.) Vog., Mollinedia schottiana (Spreng.) Perk. e Polygala klotzschii Chad.;

- Em todas as espécies estudadas os sistemas subterrâneos gemíferos são de natureza radicular;

- Das oito espécies analisadas, apenas em I. fagifolia o cilindro vascular da raiz gemifera é do tipo sifonostelo;

- Nas espécies estudadas, o amido constitui o principal composto de reserva das raízes, sendo armazenado, principalmente, no parênquima axial e radial do xilema e floema secundários. Apenas em $P$. klotzschii o material de reserva predominante é constituido por substâncias graxas;

- As gemas radiculares são de origem endógena em $M$. schottiana e $C$. tomentosum e de origem exógena em $M$. stipitatum;

- Nas três espécies estudadas, as gemas são reparativas;

- M. schottiana e $C$. tomentosum formam gemas nas proximidades do câmbio vascular, enquanto as gemas de $M$. stipitatum desenvolvem-se a partir de 
meristemóides localizados na região periférica de uma proliferação parenquimática;

- A proliferação parenquimática responsável pela iniciação das gemas adventícias em $M$. stipitatum é resultante de divisões das células do periciclo, do parênquima radial floemático e do câmbio vascular;

- Não houve diferenças em relação ao sítio de iniciação das gemas de $M$. stipitatum formadas em condições de campo e em estacas radiculares;

- Em M. schottiana e M. stipitatum, as gemas originam-se assincronicamente;

- A conexão vascular entre a raiz e a gema ocorre acropetamente em $M$. schottiana e $C$. tomentosum, e acrópeta e basipetamente em $M$. stipitatum;

- Em M. stipitatum e C. tomentosum não houve a formação de gemas radiculares nas raizes submetidas aos experimentos de simulação da ação do fogo e da injúria mecânica e, deste modo, a iniciação de gemas não está relacionada estritamente às injúrias causadas ao nivel da raiz;

- Estacas radiculares de $M$. stipitatum e de $C$. tomentosum são potencialmente capazes de formar gemas adventícias, inclusive quando coletadas na área não perturbada pela ação do fogo, ou seja, na Reserva Florestal de Santa Genebra;

- Em C. tomentosum, as gemas formam-se exclusivamente na extremidade proximal da estaca enquanto que, em $M$. stipitatum, as gemas formam-se ao longo de toda a estaca;

- A formação de gemas em estacas radiculares pode estar relacionada à liberação destas da influência da dominância apical exercida pela parte aérea da planta-mãe;

- Uma vez que, após o incêndio, as espécies estudadas apresentaram a parte aérea morta ou bastante danificada, acredita-se que a ação do fogo tenha provocado alterações na dominância apical nestas espécies, promovendo um desbalanço hormonal entre a parte aérea e o sistema radicular, 
possibilitando a formação de gemas nas raízes. Desta forma, são sugeridos estudos posteriores sobre a eliminação da parte aérea das árvores ou o anelamento da região proximal das raízes superficiais, a fim de confirmar estas observações. Estas análises não puderam ser efetuadas nas áreas de estudo por tratarem de Reservas Florestais do Estado de São Paulo. 


\section{REFERÊNCIAS BIBLIOGRÁFICAS}

ACHUTTI, M.H.C. Aspectos morfológicos e anatômicos dos sistemas aéreo e subterrâneo e o óleo essencial das folhas de Piptocarpha rotundifolia (Less.) Baker (Compositae). São Paulo, 1978. 212p. Tese (Doutorado) - Instituto de Biociências, Universidade de São Paulo.

AIDAR, M.P.M. Ecologia do araribá (Centrolobium tomentosum Guill. ex Benth - Fabaceae) e o ecótono mata ciliar da Bacia do Rio Jacaré-Pepira, São Paulo. Campinas, 1992. 100p. Dissertação (Mestrado) - Instituto de Biologia, Universidade Estadual de Campinas.

ALVES DE BRITO, C.J.F.; ALQUINI, Y. A new method for staining botanical material embedded in glycol methacrylate (GMA). Arquivos de Biologia e Tecnologia, v.39, n.4, p.949-951, dez. 1996.

APPEZZATO, B. Desenvolvimento anatômico e propagação vegetativa de Mandevilla velutina var. glabra (Muell.-Arg.) Woodson - Apocynaceae. São Paulo, 1988. 88p. Dissertação (Mestrado) - Instituto de Biociências, Universidade de São Paulo. 
APPEZZATO-DA-GLÓRIA, B.; ESTELITA, M.E.M. Caracteres anatômicos da propagaçäo vegetativa de Mandevilla illustris (Vell.) Woodson e de $M$. velutina (Mart. ex Stadelm.) Woodson - Apocynaceae. In: CONGRESSO DA SOCIEDADE BOTÂNICA DE SÃO PAULO, 9., Ilha Solteira, 1995. Anais. Ilha Solteira: SBSP, 1995. p.5-13.

BAIRD, J.H.; DUTE, R.R.; DICKENS, R. Ontogeny, anatomy, and reproductive biology of vegetative reproductive organs of Diodia virginiana L. (Rubiaceae). International Journal of Plant Sciences, v.153, n.3, p.320-328, 1992.

BAKSHI, T.S.; COUPLAND, R.T. An anatomical study of the subterranean organs of Euphorbia esula in relation to its control. Canadian Journal of Botany, v.37, n.4, p.613-620, July 1959.

BAKSHI, T.S.; COUPLAND, R.T. Vegetative propagation in Linaria vulgaris. Canadian Journal of Botany, v.38, n.2, p.243-249, Mar. 1960.

BASKIN, J.M.; BASKIN, C.C. Temperature relations for bud growth in the root geophyte Pediomelum subacaule and ecological implications. Botanical Gazette, v.151, n.4, p.506-509, Dec. 1990.

BELL, A.D. Plant form: an illustrated guide to flowering plant morphology. Oxford: Oxford University Press, 1993. 341p.

BELL, T.L.; PATE, J.S.; DIXON, K.W. Relationships between fire response, morphology, root anatomy and starch distribution in south-west Australian Epacridaceae. Annals of Botany, v.77, n.4, p.357-364, Apr. 1996. 
BONNETT JR, H.T.; TORREY, J.G. Chemical control of organ formation in root segments of Convolvulus cultured in vitro. Plant Physiology, v.40, n.6, p.1228-1236, Nov. 1965.

BONNETT JR, H.T.; TORREY, J.G. Comparative anatomy of endogenous bud and lateral root formation in Convolvulus anvensis roots cultured in vitro. American Journal of Botany, v.53, n.5, p.496-507, May/June 1966.

BOWEN, B.J.; PATE, J.S. The significance of root starch in post-fire shoot recovery of the resprouter Stirlingia latifolia $\mathrm{R}$. Br. (Proteaceae). Annals of Botany, v.72, n.1, p.7-16, July 1993.

BROWN, C.L. Primary growth. In: ZIMMERMANN, M.H.; BROWN, C.L. (Ed.) Trees: structure and function. New York: Springer-Verlag, 1974. cap.1, p.1-66.

BROWSE, P.M. A propagação das plantas. 2.ed. S.I.: Publicações EuropaAmérica, 1979. 229p.

BURROWS, G.E. Anatomical aspects of root bud development in hoop pine (Araucaria cunninghamii). Australian Journal of Botany, v.38, n.1, p.73$78,1990$.

CARLSON, G.E. Photoperiodic control of adventitious stem initiation on roots. Crop Science, v.5, n.3, p.248-250, May/June 1965.

CARLSON, G.E.; SPRAGUE, V.G.; WASHKO, J.B. Effects of temperature, daylength, and defoliation on the creeping-rooted habit of alfafa. Crop Science, v.4, n.3, p.284-286, May/June 1964. 
CASTELLANI, T.T. Sucessão secundária inicial em mata tropical semidecídua, após perturbação por fogo. Campinas, 1986. 180 p. Dissertação (Mestrado) - Instituto de Biologia, Universidade Estadual de Campinas.

CHARLTON, W.A. Bud initiation in excised roots of Linaria vulgaris. Nature, v.207, n.4998, p.781-782, Aug. 1965.

CHARLTON, W.A. The root system of Linaria vulgaris Mill. I. morphology and anatomy. Canadian Journal of Botany, v.44, n.9, p.1111-1116, Sep. 1966.

COUPLAND, R.T.; ALEX, J.F. Distribution of vegetative buds on the underground parts of leafy spurge (Euphorbia esula L.) Canadian Journal of Agricultural Science, v.35, n.1, p.76-82, Jan./Feb. 1955.

COUPLAND, R.T.; SELLECK, G.W.; ALEX, J.F. The reproductive capacity of vegetative buds on the underground parts of leafy spurge (Euphorbia esula L.). Canadian Joumal of Agricultural Science, v.35, n.5, p.477-484, Sep./Oct. 1955.

DIETRICH, S.M.C.; FIGUEIREDO-RIBEIRO, R.C.L. Organos subterraneos y propagacion vegetativa en plantas de los cerrados brasileros. Medio Ambiente, v.7, n.2, p.45-52, 1985.

DIETRICH, S.M.C.; FIGUEIREDO-RIBEIRO, R.C.L. Carboidratos de reserva em plantas superiores e sua importância para o homem. Revista de la Academia Colombiana de Ciencias Exactas, Físicas e Naturales, v.16, n.61, p. 65-71, nov. 1986. 
DIETRICH, S.M.C.; FIGUEIREDO-RIBEIRO, R.C.L.; CHU, E.P.; BUCKERIDGE, M.S. O açúcar das plantas. Ciência Hoje, v.7, n.39, p.42-48, jan./fev. 1988.

DIRR, M. A.; HEUSER JR, C.W. The reference manual of woody plant propagation from seed to tissue culture. Athens: Varsity Press, 1987. cap.2, p.23-53: Cutting propagation.

DORE, J. Studies in the regeneration of horseradish. I. a re-examination of the morphology and anatomy of regeneration. Annals of Botany, v.19, n.73, p.127-137, Jan. 1955.

ELIASSON, L. The influence of growth substances on the formation of shoots from aspen roots. Physiologia Plantarum, v.14, n.1, p.150-156, 1961.

ELIASSON, L. Growth regulators in Populus tremula. I. distribution of auxin and growth inhibitors. Physiologia Plantarum, v.22, n.6, p.1288-1301, 1969.

ELIASSON, L. Growth regulators in Populus tremula. III. variation of auxin and inhibitor level in roots in relation to root sucker formation. Physiologia Plantarum, v.25, n.1, p.118-121, 1971a.

ELIASSON, L. Growth regulators in Populus tremula. IV. apical dominance and suckering in young plants. Physiologia Plantarum, v.25, n.2, p.263-267, $1971 b$.

ESAU, K. Plant anatomy. 2.ed. New York: John Wiley \& Sons, 1965. 767p. 
EWEL, J.; BERISH, C.; BROWN, B.; PRICE, N.; RAICH, J. Slach and burn impacts on a Costa Rican wet forest site. Ecology, v.62, n.3, p.816-829, 1981.

FARMER JR, R.E. Aspen root sucker formation and apical dominance. Forest Science, v.8, n.4, p.403-410, Dec. 1962.

FIGUEIREDO-RIBEIRO, R.C.L.; DIETRICH, S.M.C. Variações estacionais nos compostos de reserva e no metabolismo do xilopódio de Ocimum nudicaule Benth. var. anisifolia Giul. (Labiatae). Revista Brasileira de Botânica, v.4, n.2, p.73-82, dez. 1981.

FIGUEIREDO-RIBEIRO, R.C.L.; DIETRICH, S.M.C.; CHU, E.P.; MACHADO DE CARVALHO, M.A.; VIEIRA, C.C.J.; GRAZIANO, T.T. Reserve carbohydrates in underground organs of native Brazilian plants. Revista Brasileira de Botânica, v.9, n.2, p.159-166, dez. 1986.

FISHER, D.B. Protein staining of ribboned epon sections for light microscopy. Histochemie, v.16, p. 92-96, 1968.

GERLACH, G. Botanische microtechnik, eine einführung. Stuttgart: Georg Thieme, 1969.

GREIG, N.; MAUSETH, J.D. Structure and function of dimorphic prop roots in Piper auritum L. Bulletin of the Torrey Botanical Club, v.118, n.2, p.176183, Apr./June 1991. 
HARTMANN, H.T.; KESTER, D.E.; DAVIES JR, F.T. Plant propagation: principles and practices. 5.ed. Englewood Cliffs: Prentice-Hall, 1990. cap.9, p.199-255: Anatomical and physiological basis of propagation by cuttings.

HORRIDGE, G.A.; TAMM, S.L. Critical point drying for scanning electron microscopy study of ciliary motion. Science, v.163, n.3869, p.817-818, Feb. 1969.

HUDSON, J.P. Factors affecting the regeneration of root-cuttings. Nature, v.172, n.4374, p.411-412, Aug. 1953.

HUDSON, J.P. Propagation of plants by root cuttings I. regeneration of raspberry root cuttings. Journal of Horticultural Science, v.29, p.27-43, 1954.

HUDSON, J.P. Propagation of plants by root cuttings II. seasonal fluctuation of capacity to regenerate from roots. Journal of Horticultural Science, v.30, p.242-251, 1955.

INSTITUTO FLORESTAL. Secretaria do Meio Ambiente. Coordenadoria de Informações Técnicas, Documentação e Pesquisa Ambiental. Padronização de critérios para a descrição anatômica da casca: lista de caracteristicas e glossário de termos. São Paulo, 1996. 25p. (Série Registros)

JANZEN, D.H. Ecologia vegetal nos trópicos. São Paulo: Editora Pedagógica e Universitária, 1980. 79p. (Coleção Temas de Biologia, 7). 
JENÍK, J. Clonal growth in woody plants: a review. Folia Geobotanica Phytotaxonomica, v.29, p. 291-306, 1994.

JENSEN, W.A. Botanical histochemistry: principle and practice. San Francisco: W.H. Freeman, 1962. 408p.

JOHANSEN, D.A. Plant microtechnique. New York: McGraw-Hill Book Compeny, 1940, 528p,

KARNOVSKY, M.J. A formaldehyde-glutaraldehyde fixative of high osmolality for use in electron microscopy. Journal of Cell Biology, v.27, p.137-138, 1965.

KAUFFMAN, J.B. Survival by sprouting following fire in tropical forests of the eastern Amazon. Biotropica, v.23, n.3, p.219-224, 1991.

KEFFORD, N.P.; CASO, O.H. Organ regeneration on excised roots of Chondrilla juncea and its chemical regulation. Australian Journal of Biological Sciences, v.25, n.4, p.691-706, Aug. 1972.

KIRIZAWA, M. Contribuição ao conhecimento morfo-ecológico e do desenvolvimento anatômico dos órgãos vegetativos e de reprodução de Cochlospermum regium (Mart. \& Schr.) Pilger - Cochlospermaceae. São Paulo, 1981. 437p. Tese (Doutorado) - Instituto de Biociências, Universidade de São Paulo.

$\mathrm{KOOP}, \mathrm{H}$. Vegetative reproduction of trees in some European natural forests. Vegetatio, v.72, p.103-110, 1987 
LACEY, C.J.; JOHNSTON, R.D. Woody clumps and cumpwoods. Australian Journal of Botany, v.38, n.3, p.299-334, 1990.

LEAKEY, R.R.B. The capacity for vegetative propagation in trees. In: CANNELL, M.G.R.; JACKSON, J.E. (Ed.) Attributes of trees as crop plants. Kendal: Institute of Terrestrial Ecology, 1985. p.110-133.

MacDONALD, B. Practical woody plant propagation for nursery growers. Portland: Timber Press, $1993 . \quad$ cap.14, p.391-402: Root cuttings and division.

MAHLSTED, J.P.; HARBER, E.S. Plant propagation. New York: John Wiley \& Sons, 1957. cap.13, p.191-228: Cuttage.

MATTHES, L.A.F. Dinâmica da sucessão secundária em mata, após a ocorrência de fogo - Santa Genebra - Campinas, São Paulo. Campinas, 1992. 216p. Tese (Doutorado) - Instituto de Biologia, Universidade Estadual de Campinas.

MURRAY, B.E. The ontogeny of adventitious stems on roots of creeping-rooted alfafa. Canadian Journal of Botany, v.35, n. 4, p.463-475, July 1957.

MYERS, G.A.; BEASLEY, C.A.; DERSCHEID, L.A. Anatomical studies of Euphorbia esula L. Weeds, v.12, n.4, p.291-295, Oct. 1964.

NADEAU, L.B.; VANDEN BORN, W.H. The root system of Canada thistle. Canadian Journal of Plant Science, v.69, n.4, p.1199-1206, Oct. 1989. 
PAUKKONEN, K.; KAUPPI, A.; FERM, A. Root and stump buds as structural faculties for reinvigoration in Alnus incana (L.) Moench. Flora, v.187, p.353367, 1992.

PAVIANI, T.I. Anatomia do desenvolvimento do xilopódio de Brasilia sickii G.M. Barroso. Estágio inicial. Ciência e Cultura, v.39, n.4, p.399-405, abr. 1987.

PAVIANI, T.I.; MAGALHÃES, M.P. Propagação vegetativa em Casearia sylvestris SW (Flacourtiaceae). In: CONGRESSO NACIONAL DE BOTÂNICA, 47., Nova Friburgo, 1996. Resumos. Nova Friburgo: s. ed., 1996. p. 248.

PETERSON, R.L. Bud development at the root apex of Ophioglossum petiolatum. Phytomorphology, v.20, n.2, p.183-190, June 1970.

PETERSON, R.L. The initiation and development of root buds. In: TORREY, J.G.; CLARKSON, D.T. (Ed.) The development and function of roots. London: Academic Press, 1975. cap. 7, p.125-161.

PETERSON, R.L.; THOMAS, A.G. Buds on the roots of Hieracium florentinum (hawkweed). Canadian Journal of Botany, v.49, n.1, p.53-54, Jan. 1971.

POLOWICK, P.L.; RAJU, M.V.S. The origin and development of root buds in Asclepias syriaca. Canadian Journal of Botany, v.60, n.10, p.2119-2125, Oct. 1982.

PRIESTLEY, J.H.; SWINGLE, C.F. Vegetative propagation from the standpoint of plant anatomy. USDA Technical Bulletin, n.151, p.1-98, Dec. 1929. 
RAJU, M.V.S.; COUPLAND, R.T; STEEVES, T.A. On the occurrence of root buds on perennial plants in Saskatchewan. Canadian Journal of Botany, v.44, n.1, p.33-37, Jan. 1966.

RIZZINI, C.T. Estudos experimentais sobre o xilopódio e outros órgãos tuberosos de plantas do cerrado. Anais da Academia Brasileira de Ciências, v.37, n.1, p.87-113, mar. 1965.

RIZZINI, C.T.; HERINGER, E.P. Studies on the underground organs of trees and shrubs from some southern Brazilian savannas. Anais da Academia Brasileira de Ciências, v.34, n.2, p.235-247, jun. 1962.

RIZZINI, C.T.; HERINGER, E.P. Estudo sobre os sistemas subterrâneos difusos de plantas campestres. Anais da Academia Brasileira de Ciências, v.38, p.85-112, dez. 1966. Suplemento: II Simpósio sobre cerrado.

RODRIGUES, R.R.; MATTHES, L.A.F.; TORRES, R.B. Espécies arbóreas distribuição agregada ou reprodução vegetativa?. In: CONGRESO LATINOAMERICANO DE BOTANICA, 5., Havana, 1990. Resumos. Havana: s.ed., 1990. p. 122.

ROESER, K.R. Die nadel der schwarzkiefer-massen produkt und kunstwert der natur. Mikrokosmos, v.61, p.33-36, 1972.

ROOD, S.B.; HILLMAN, C.; SANCHE, T.; MAHONEY, J. Clonal reproduction of riparian cottonwoods in southern Alberta. Canadian Journal of Botany, v.72, n.12, p.1766-1774, Dec. 1994. 
SAKAI, W.S. Simple method for differential staining of paraffin embedded plant material using toluidine blue O. Stain Technology, v.48, n.5, p.247-249, 1973.

SANDBERG, D. The regeneration of quaking aspen by root suckering. 1951. Master (M.S.) - School of Forestry, University of Minnesota.

SANER, M.A.; CLEMENTS, D.R.; HALL, M.R.; DOOHAN, D.J.; CROMPTON, C.W. The biology of Canadian weeds. 105. Linaria vulgaris Mill. Canadian Journal of Plant Science, v.75, n.2, p.525-537, Apr. 1995.

SASS, J.E. Botanical microtechnique. Ames: lowa State University, 1951. $228 p$.

SCHIER, G.A. Origin and development of aspen root suckers. Canadian Journal of Forest Research, n.3, p.45-53, 1973a.

SCHIER, G.A. Seasonal variation in sucker production from excised roots of Populus tremuloides and the role of endogenous auxin. Canadian Journal of Forest Research, n.3, p.459-461, 1973b.

SIEGLER, E.A.; BOWMAN, J.J. Anatomical studies of root and shoot primordia in 1-year apple roots. Journal of Agricultural Research, v.58, n.11, p.795803, June 1939.

STERRETT, J.P.; CHAPPELL, W.E.; SHEAR, G.M. Temperature and annual growth cycle effects on root suckering in black locust. Weed Science, v.16, n.2, p.250-251, Apr. 1968. 
STRASBURGER, E. Handbook of practical botany. 7.ed. London: George Allen, 1913. 527p.

TAYLOR, G. The origin of adventitious growth in Acanthus montanus. Transactions and Proceedings of the Botanical Society of Edinburgh, v.29, p.291-296, 1926.

UHL, C. Recovery following disturbances of different intensities in the Amazon rain forest of Venezuela. Interciencia, v.7, n.1, p.19-24, Ene/Feb. 1982.

UHL, C.; CLARK, K.; CLARK, H.; MURPHY, P. Early plant sucession after cutting and burning in the upper Rio Negro region of the Amazon basin. Journal of Ecology, v.69, p.631-649, 1981.

WARDLAW, C.W. Endogenous buds in Ophioglossum vulgatum L. Nature, v.171, n.4341, p.88-89, Jan. 1953.

WILKINSON, R.E. Adventitious shoots on saltcedar roots. Botanical Gazette, v.127, n.2-3, p.103-104, June/Sep.1966.

WILSON, C.L. Adventitious roots and shoots in an introduced weed. Bulletin of the Torrey Club, v.54, p.35-38, 1927. 


\section{ILUSTRAÇÕES}


Figuras 1 e 2 - Aspecto geral das áreas estudadas em Campinas, São Paulo. 1 - Mata Santa Elisa, mostrando um trecho da área na qual foi realizado o levantamento das espécies arbóreas e arbustivas com raízes gemíferas. 2 - Reserva Florestal de Santa Genebra. 


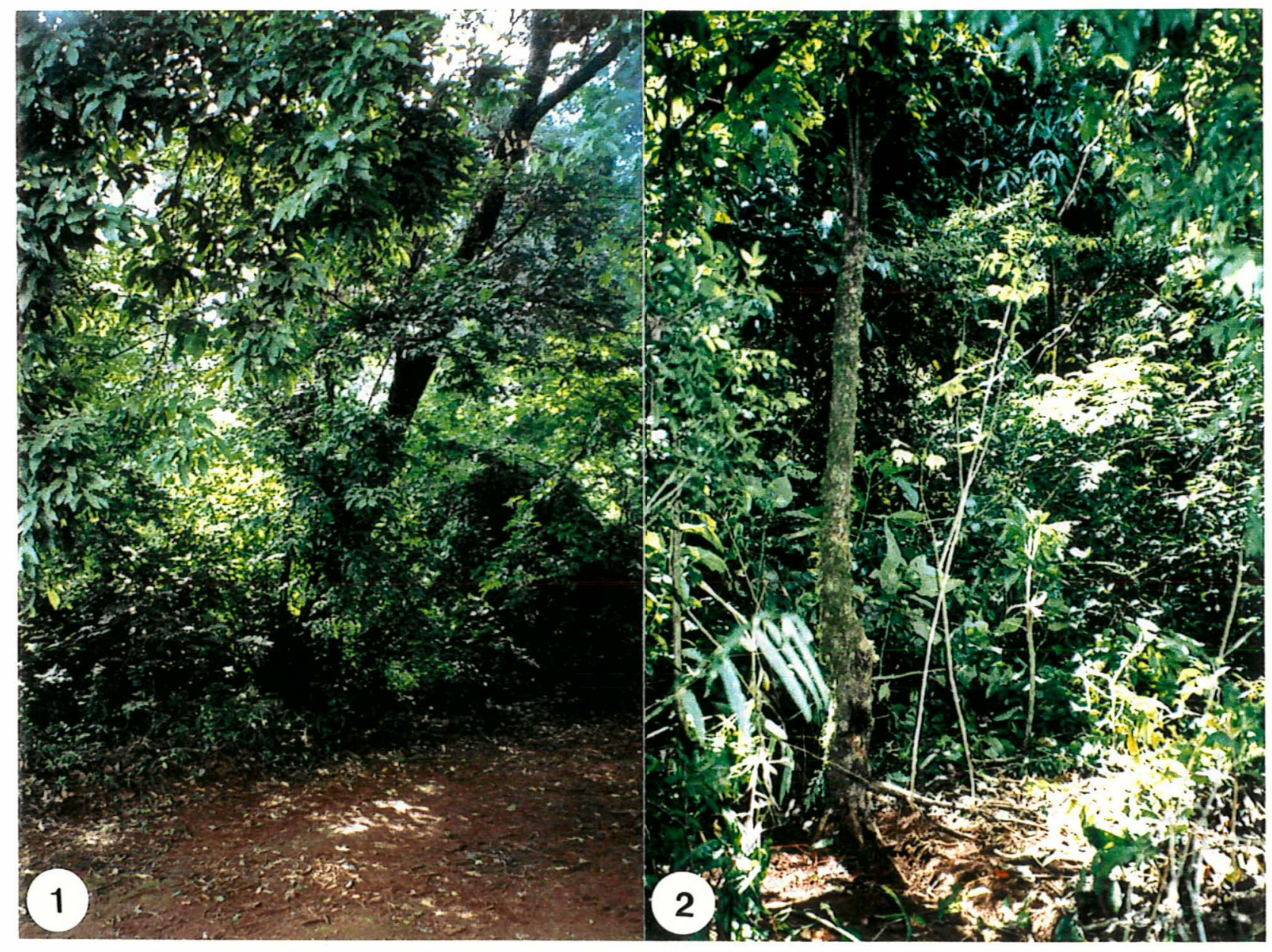


Figuras 3-6 - Instalação do experimento de simulação do fogo na indução de gemas em sistemas radiculares, na mata Santa Elisa. 3 Colocação do bagacilho de cana sobre uma raiz de $C$. tomentosum, previamente selecionada, para simular a serrapilheira presente na mata. 4 - Instalação de um termopar de cobre-constantan na superfície da raiz, sendo que a outra extremidade encontra-se conectada a um coletor e armazenador de dados. 5 - Queima do bagacilho de cana durante, aproximadamente, 180 s. 6 - Detalhe da figura anterior, mostrando a queima do bagacilho de cana. 


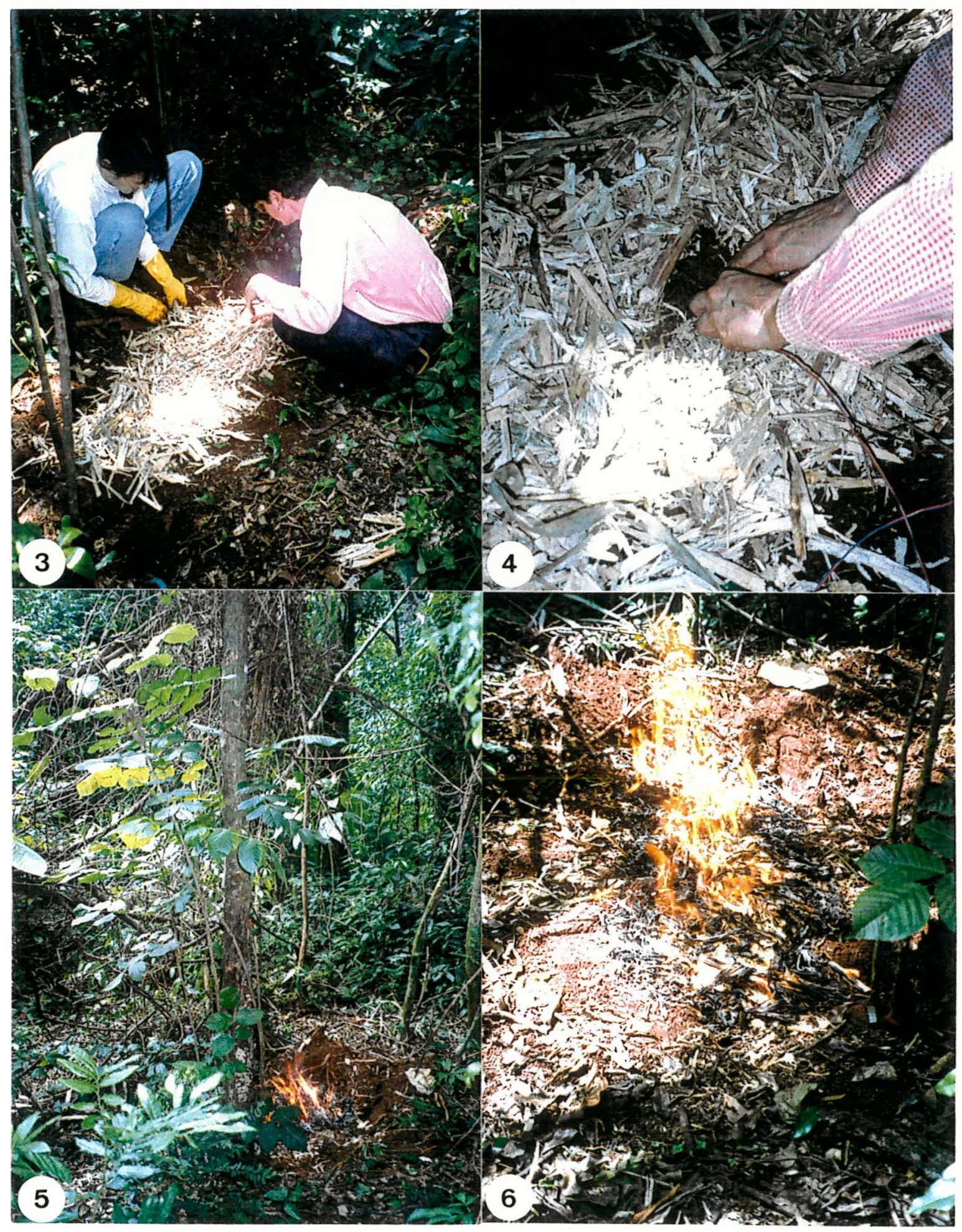


Figuras 7 e 8 - Simulação de injúria mecânica na indução de gemas em raízes. 7 - Retirada parcial da casca na porção superior de uma raiz de C. tomentosum. 8 - Detalhe desta raiz, mostrando os ferimentos. 


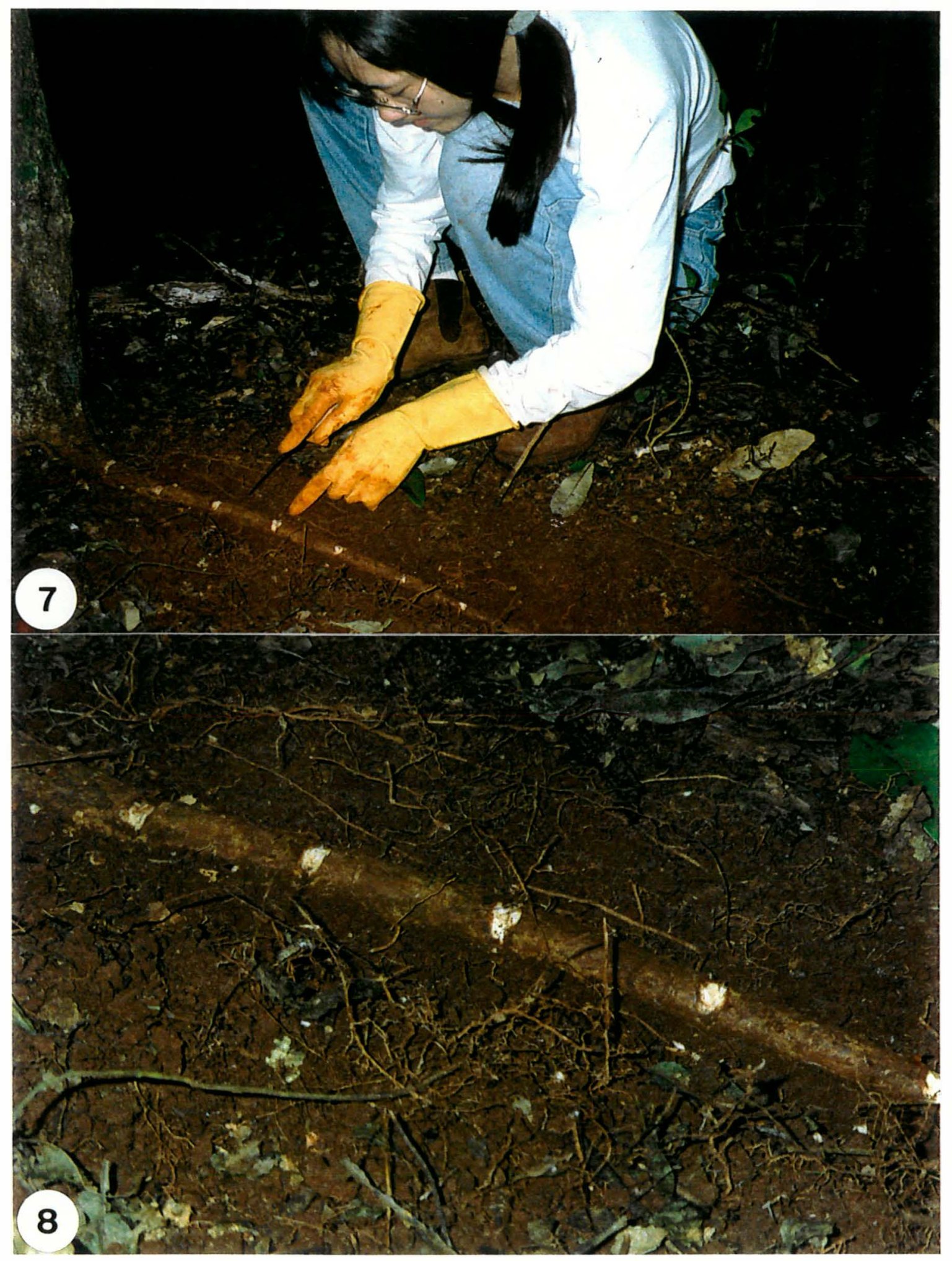


Figuras 9 e 10 - C. tomentosum. 9 - Tronco principal do indivíduo arbóreo, mostrando 2 eixos caulinares provenientes do desenvolvimento de gemas na raiz (setas). 10 - Raiz horizontal, paralela à superfície do solo, mostrando 2 eixos caulinares adjacentes (seta). 


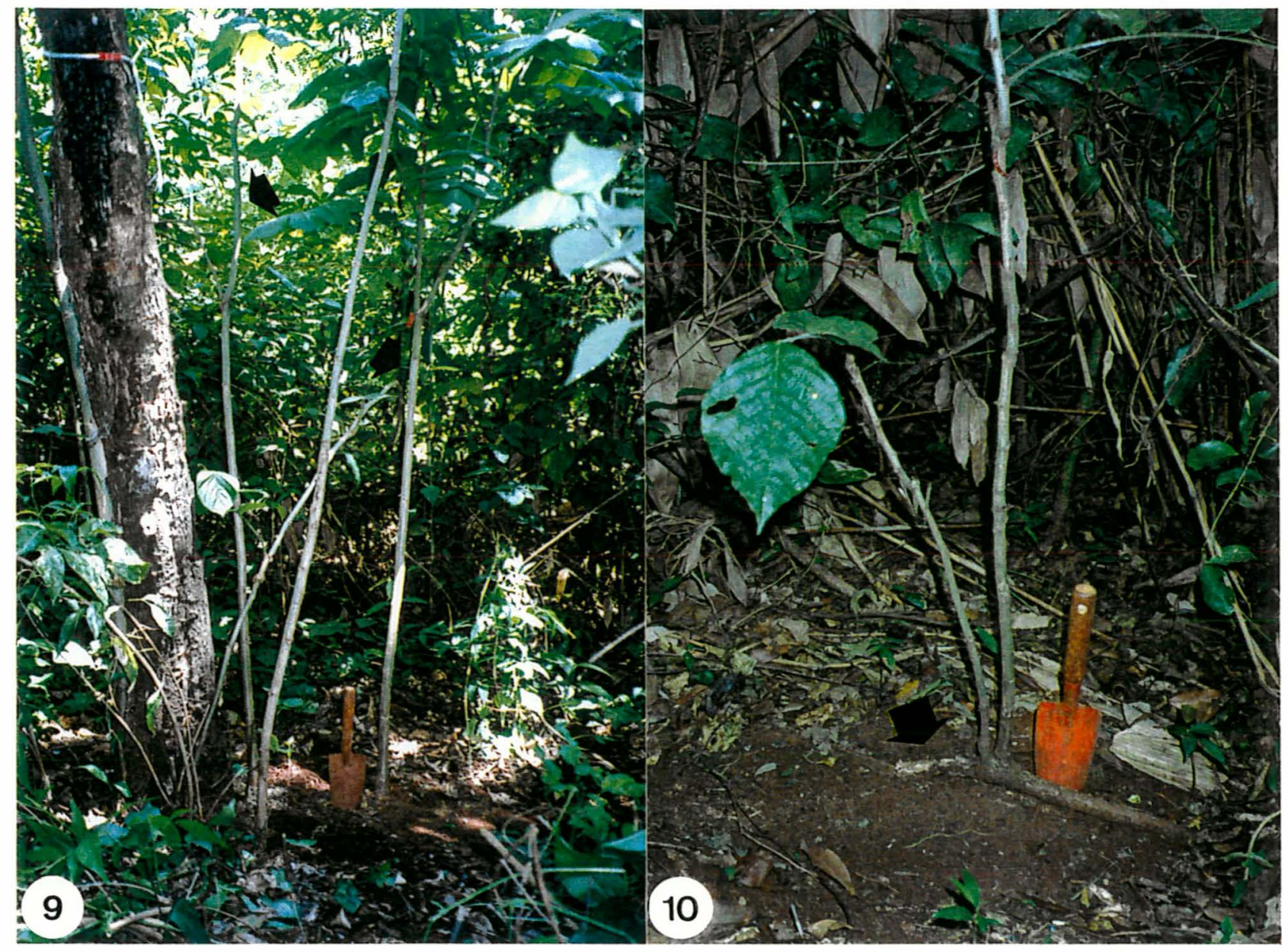


Figuras 11-14 - Eixos caulinares originados a partir de raizes horizontais, paralelas à superfície do solo. $11-\mathrm{C}$. tomentosum (barra $=$ $13,9 \mathrm{~cm}$ ). $12-$ L. cultratus (barra $=15,6 \mathrm{~cm}$ ). $13-M$. stipitatum (barra $=12,5 \mathrm{~cm}$ ). $14-$ M. schottiana (barra $=4,0$ $\mathrm{cm})$. 


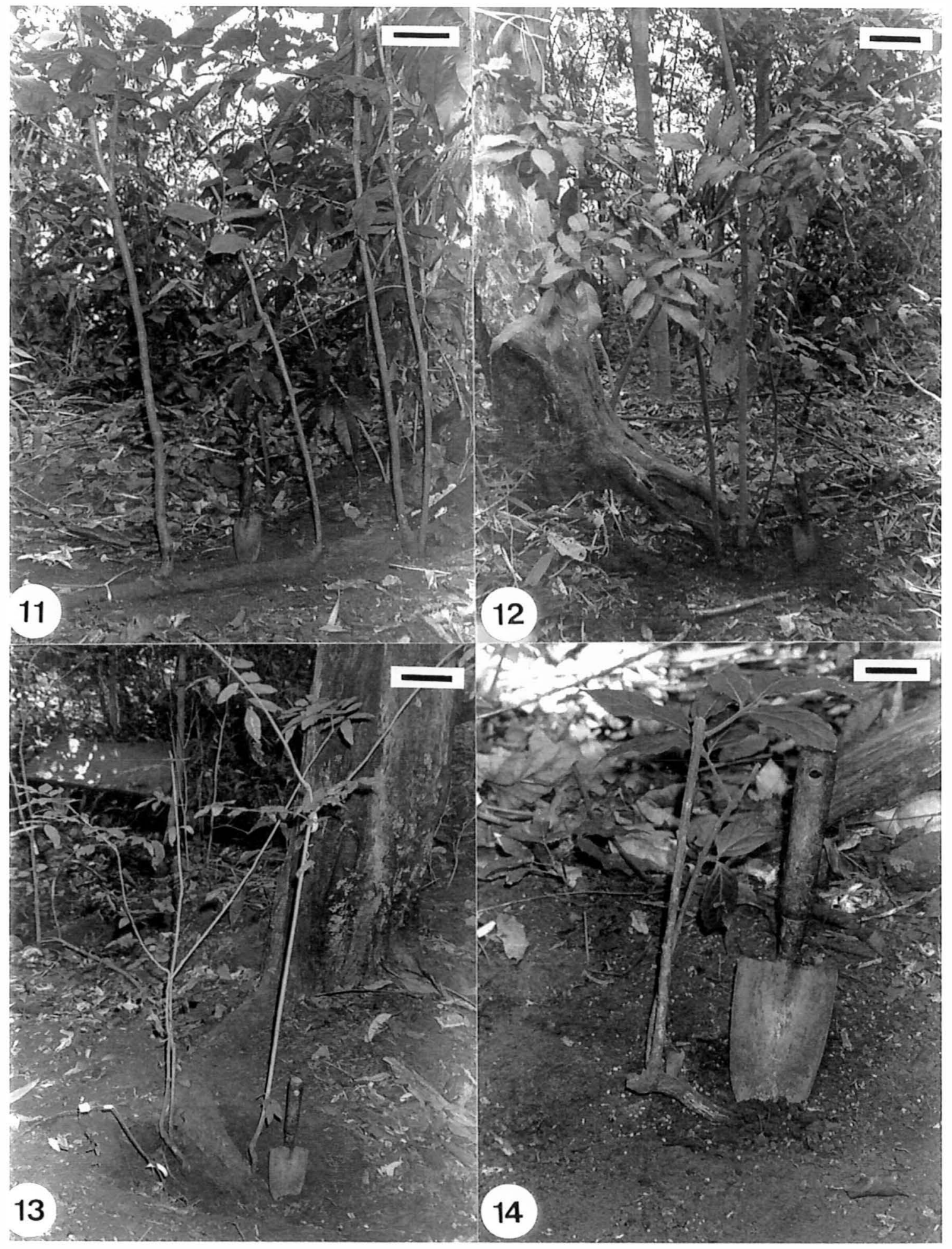


Figuras 15-22 - Detalhe do cilindro vascular das raízes gemíferas em secção transversal. $15-$ B. forficata. $16-$ C. tomentosum. $17-E$. febrifuga. $18-$ I. fagifolia. $19-$ L. cultratus. $20-$ M. stipitatum. 21. M. schottiana. 22. P. klotzschii. (barras $=153,5 \mu \mathrm{m}$ ). 


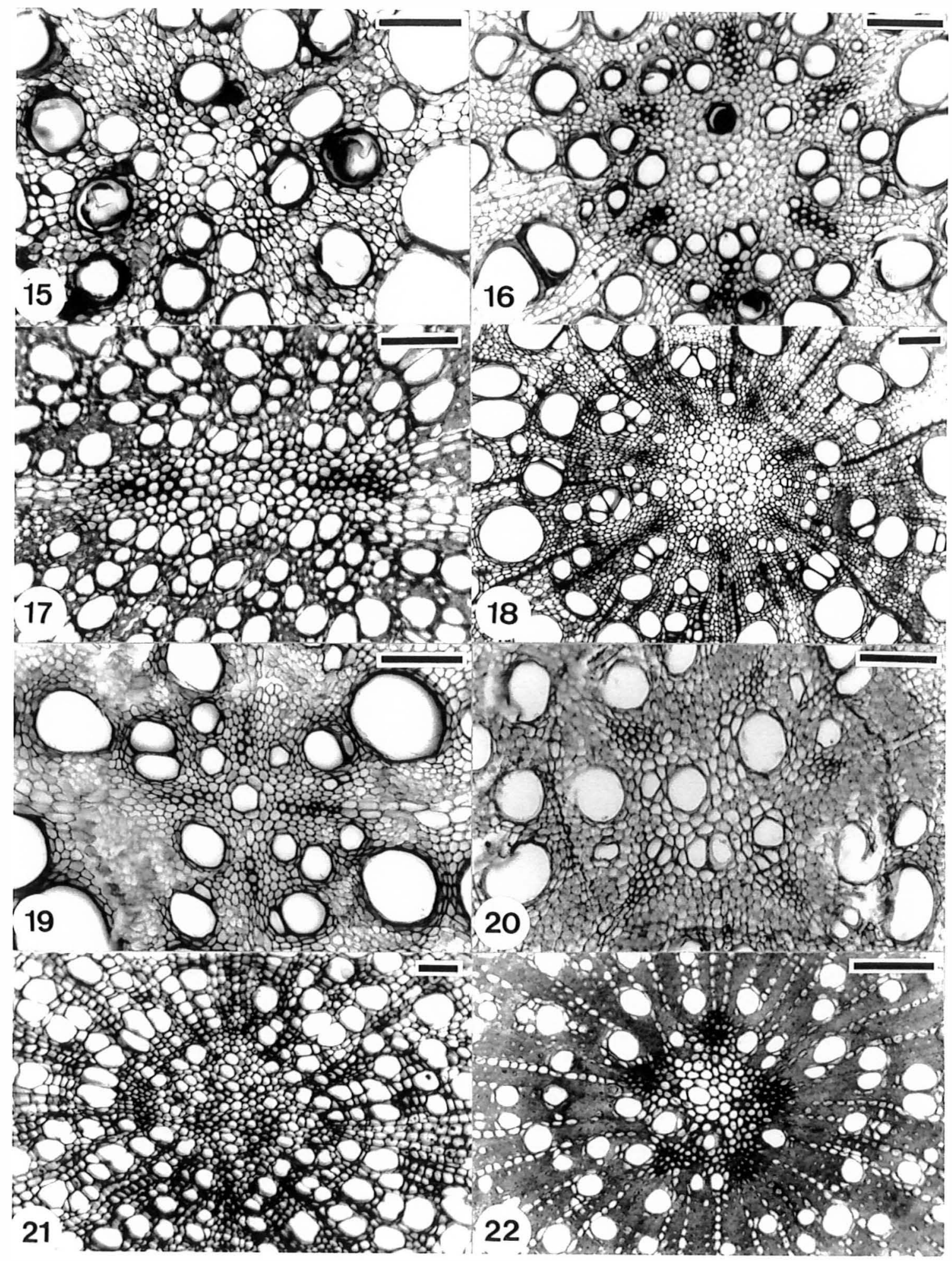


Figuras 23 e 24 - Raiz de B. forficata em secção transversal. 23 - Visão geral do xilema secundário, com as células parenquimáticas contendo reservas de amido evidenciadas pelo teste com cloreto de zinco iodado (barra $=198,9 \mu \mathrm{m}$ ). 24 - Detalhe da figura anterior, mostrando as reservas de amido (barra $=$ $36,8 \mu \mathrm{m})$. 


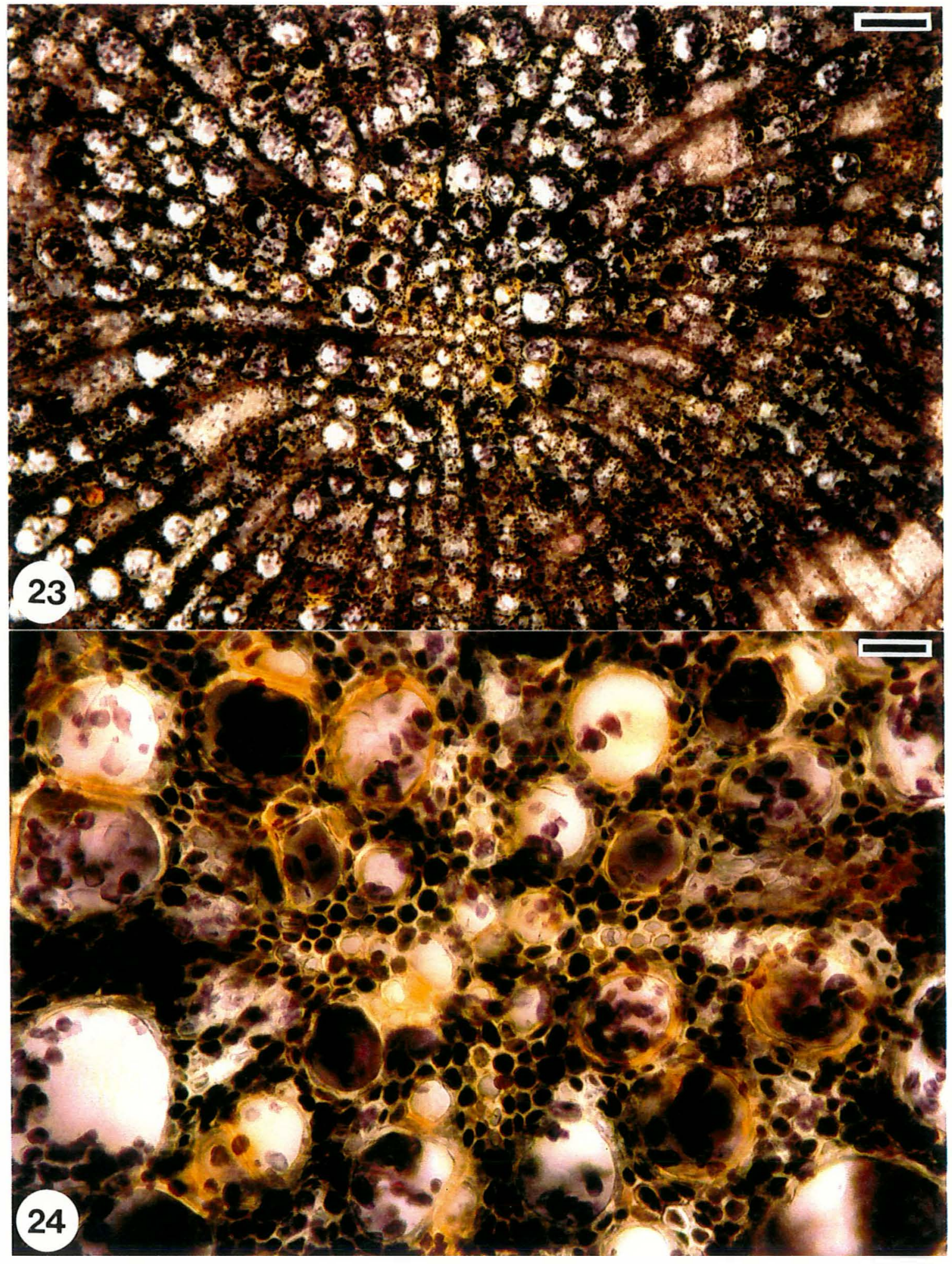


Figuras 25 e 26 - Secção transversal da raiz de $P$. klotzschii. 25 - Visão geral da raiz, a qual apresenta substâncias graxas, evidenciadas pelo corante Sudan IV, como compostos de reserva (barra $=$ 198,9 $\mu \mathrm{m}) .26$ - Detalhe das células parenquimáticas radiais do xilema secundário contendo substâncias graxas (barra = $19 \mu \mathrm{m})$. 


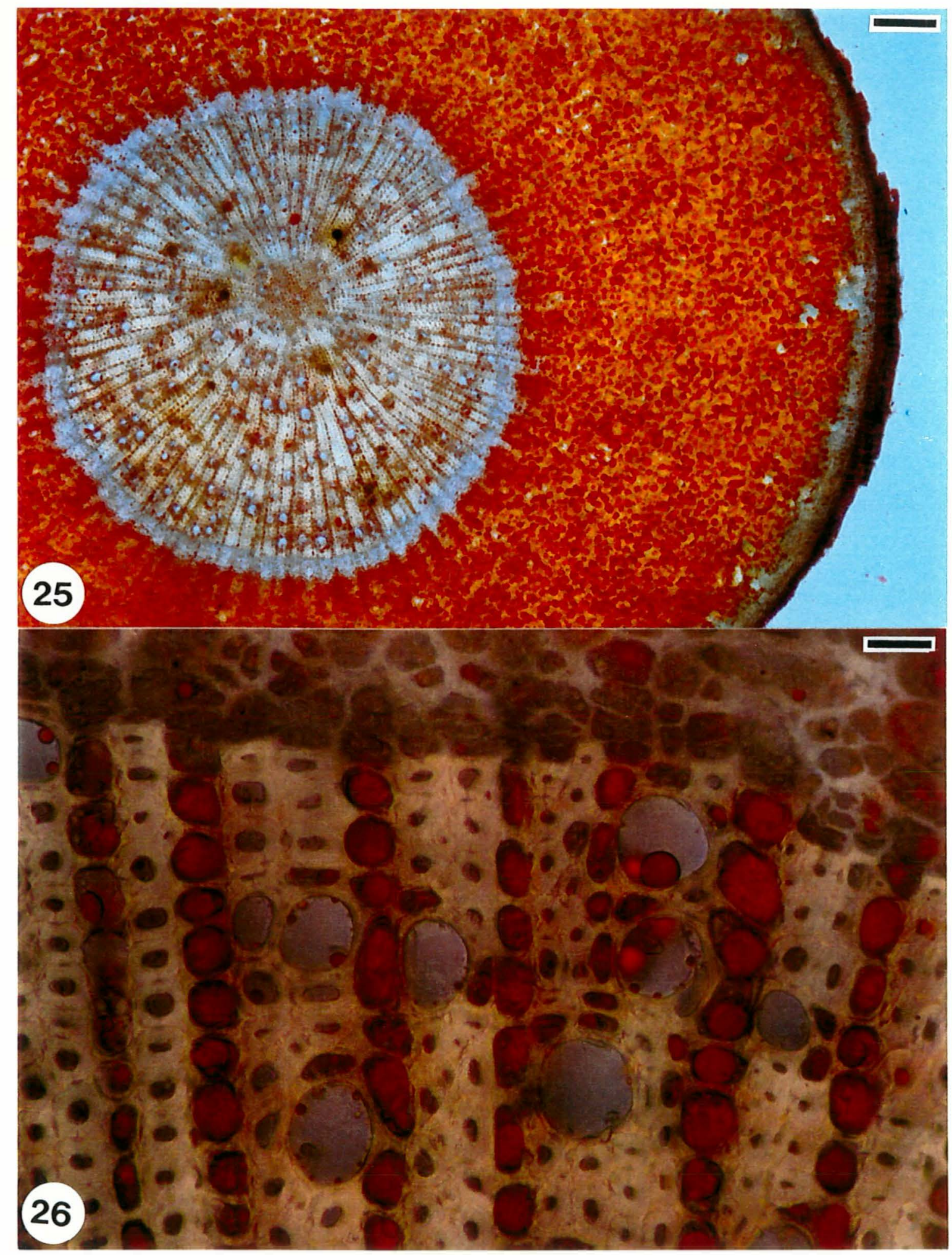


Figuras 27-29 - Gemas formadas no sistema radicular de M. schottiana, observadas ao microscópio eletrônico de varredura (MEV). 27 - Visão geral das gemas formadas assincronicamente (barra $=500 \mu \mathrm{m}) .28$ - Detalhe da gema axilar indicada pela seta na figura anterior (barra $=200 \mu \mathrm{m}$ ). 29 - Gema no início do desenvolvimento (seta) $($ barra $=250 \mu \mathrm{m})$.

Figura 30 - Secção longitudinal da gema de origem endógena de $M$. schottiana (barra $=236,8 \mu \mathrm{m})$. 


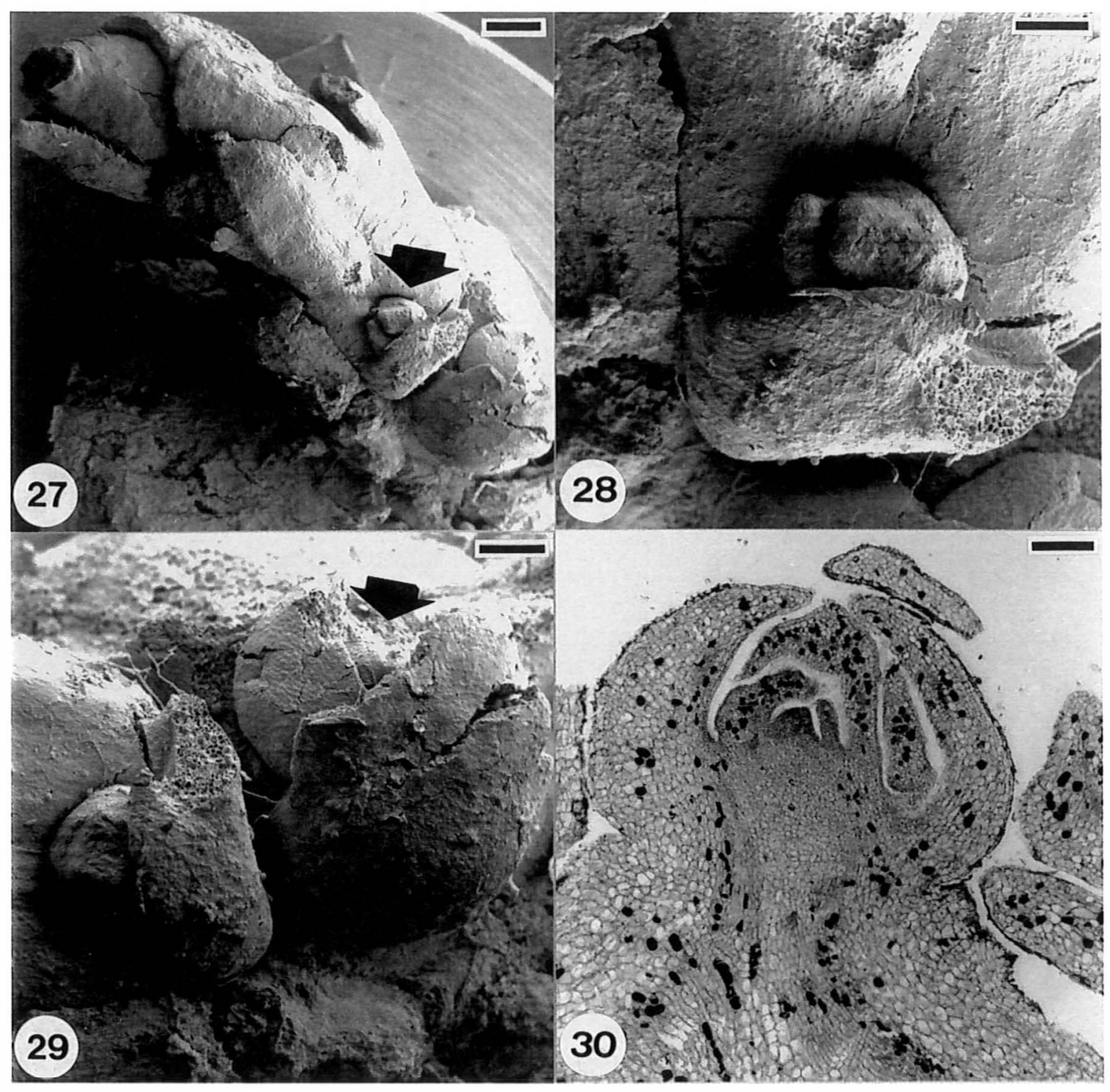


Figuras 31-33 - Secção transversal da raiz gemifera de $M$. stipitatum coletada no campo. 31 - Iniciação de primórdios de gemas na região periférica da proliferação parenquimática. A seta indica um meristemóide (barra $=198,9 \mu \mathrm{m}$ ). 32 - Gema rompendo a periderme (barra $=198,9 \mu \mathrm{m}) .33$ - Detalhe da figura anterior. Observar a gema com vários primórdios foliares (barra $=73,7$ $\mu \mathrm{m})$. Floema secundário $\left(F_{S}\right)$; periderme $\left(P_{E}\right)$. 


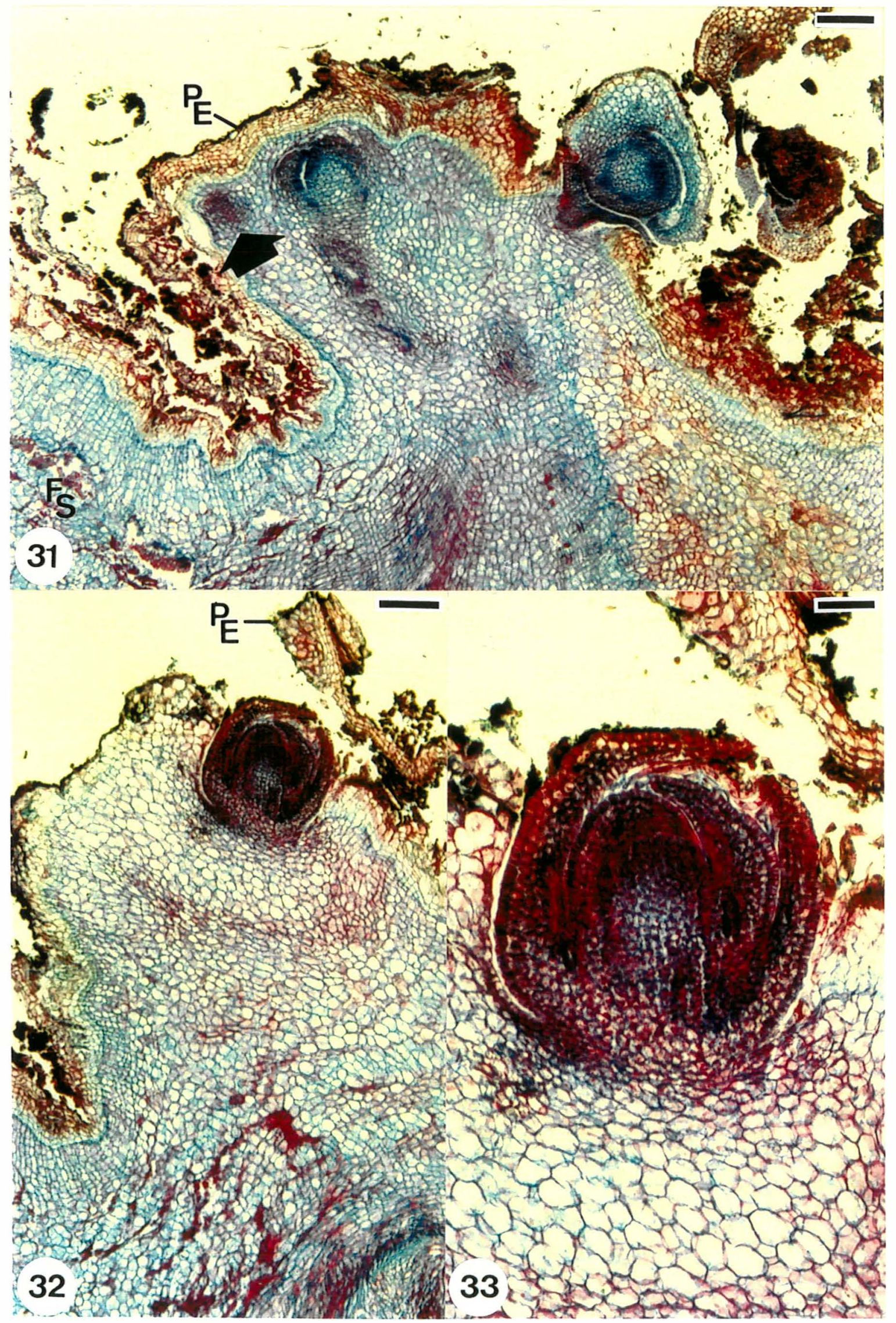


Figuras 34 e 35 - Secção transversal da estaca radicular de M. stipitatum. 34 Proliferação parenquimática originada anterior a iniciação das gemas radiculares (barra $=198,9 \mu \mathrm{m}$ ). 35 - Detalhe da proliferação, mostrando o seu desenvolvimento a partir de divisões de células próximas ao câmbio vascular (barra $=$ $73,7 \mu \mathrm{m})$. Câmbio vascular $\left(\mathrm{C}_{\mathrm{v}}\right)$; floema secundário $\left(\mathrm{F}_{\mathrm{s}}\right)$. 


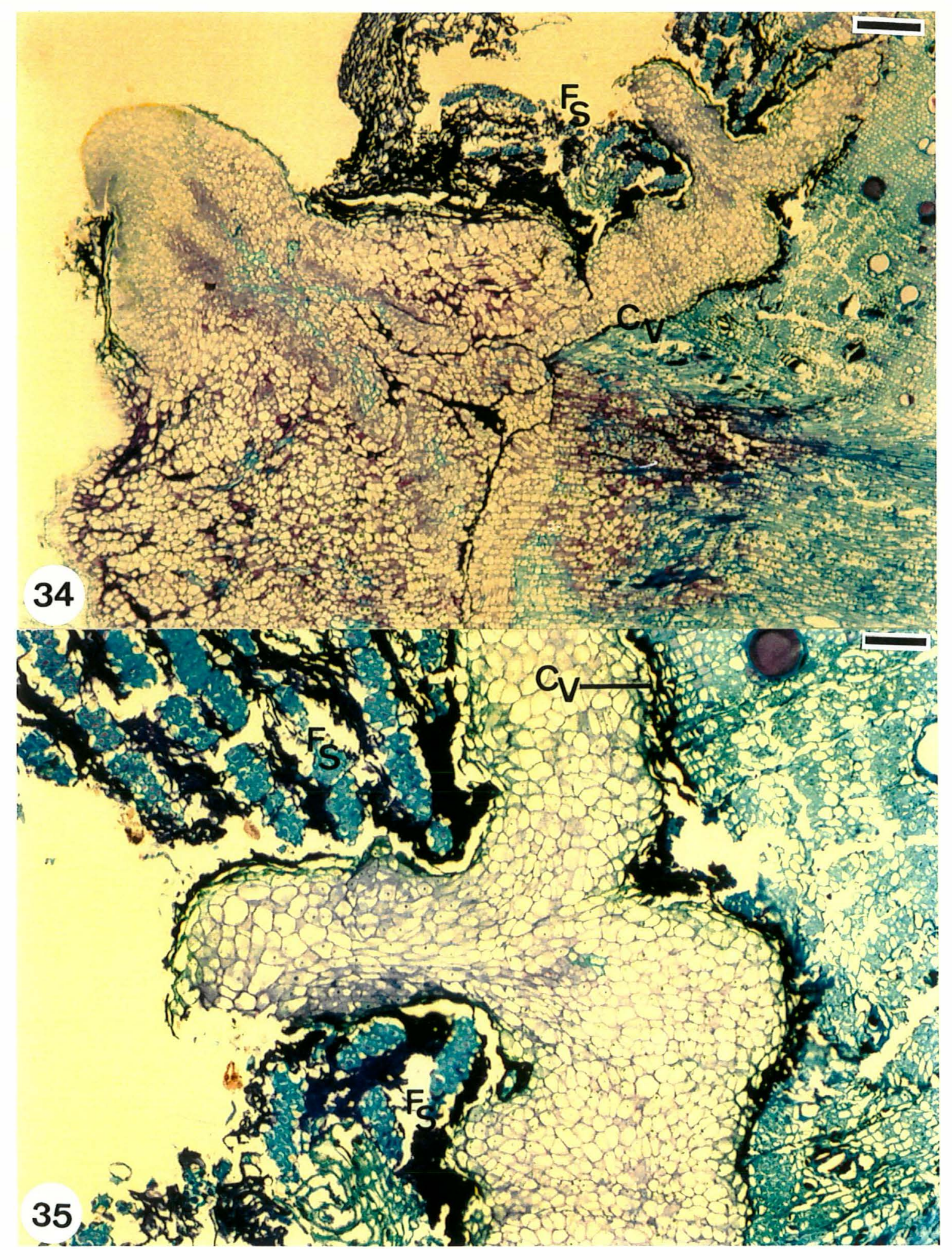


Figuras 36 e 37 - Secção transversal da estaca radicular de M. stipitatum, mostrando o início do desenvolvimento de dois primórdios de gema na região periférica da proliferação parenquimática. Observar que a conexão vascular entre a gema e a raiz-mãe ocorre através da diferenciação acrópeta $\left(A_{P}\right)$ e basípeta $\left(B_{P}\right)$ dos tecidos vasculares. (barras $=198,9 \mu \mathrm{m}$ e 73,7 $\mu \mathrm{m}$, respectivamente). Câmbio vascular $\left(C_{v}\right)$; floema secundário $\left(F_{S}\right)$. 


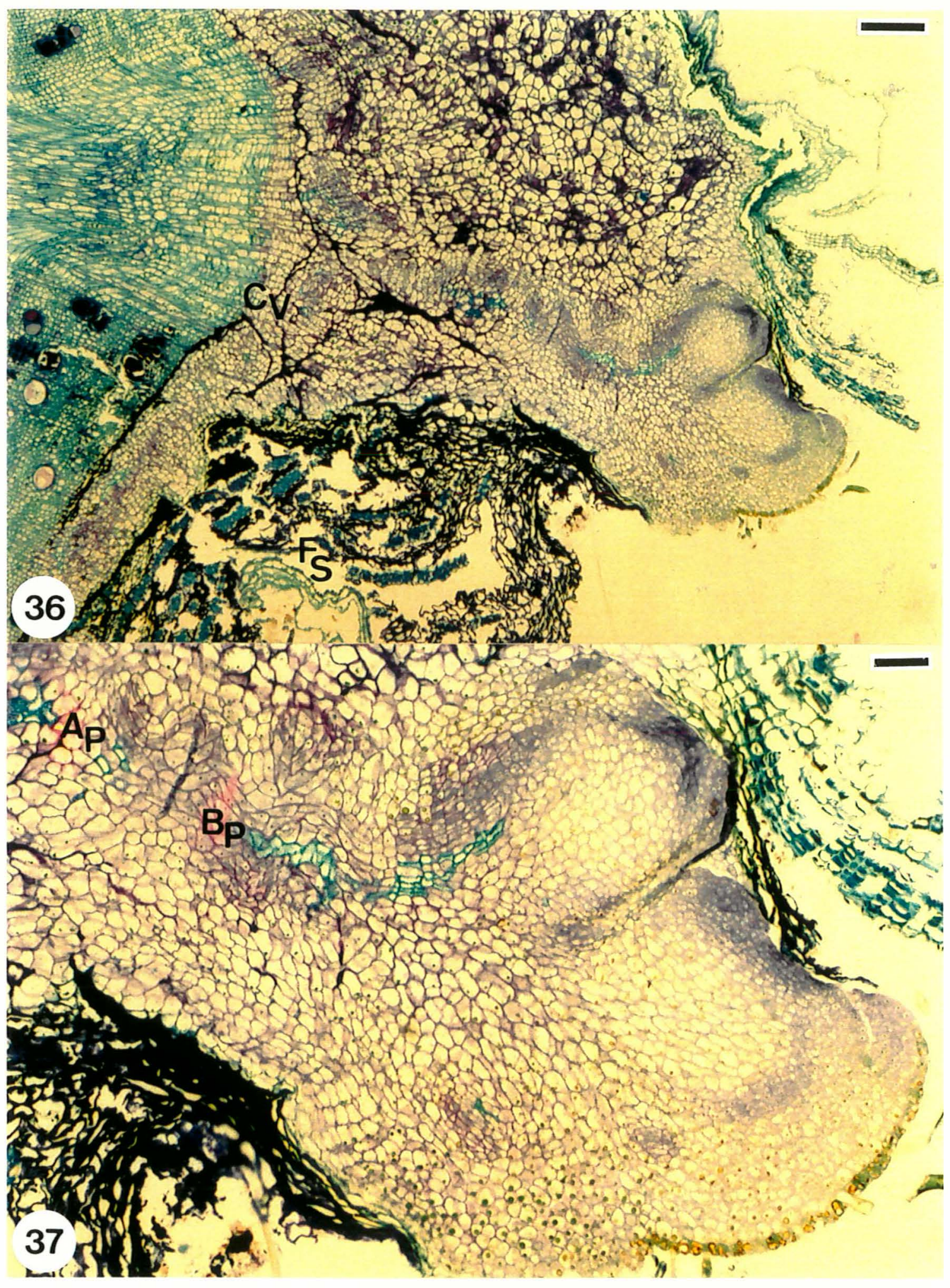


Figuras 38 e 39 - Raiz lateral da estaca radicular de M. stipitatum seccionada transversalmente. 38 - Anatomia da raiz num setor em que não há diferenciação de gemas (barra $=36,8 \mu \mathrm{m}$ ). 39 Formação de um primórdio de gema a partir da porção periférica da proliferação parenquimática (barra $=73,7 \mu \mathrm{m}$ ). Câmbio vascular $\left(C_{V}\right)$; periciclo $(P)$; raio parenquimático do floema secundário $\left(R_{P}\right)$. 


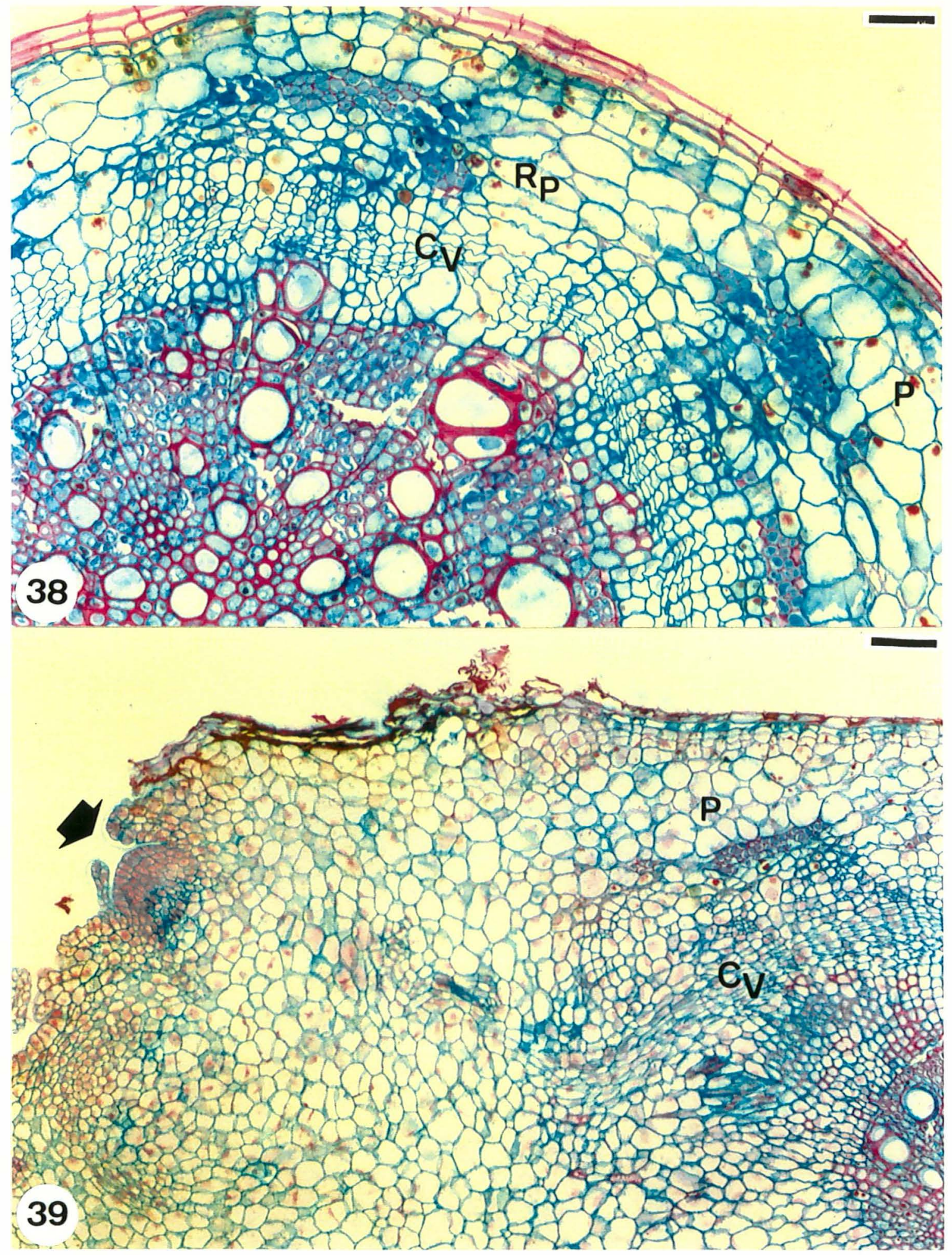


Figuras 40 e 41 - Secção transversal da raiz lateral da estaca radicular de $M$. stipitatum. 40 - Desenvolvimento de duas gemas a partir da proliferação parenquimática resultante das divisões de células derivadas do periciclo $(P)$, dos raios parenquimáticos $\left(R_{P}\right)$ e do câmbio vascular $\left(C_{v}\right)$ (barra $\left.=198,9 \mu \mathrm{m}\right) .41$ Detalhe da figura anterior (barra $=73,7 \mu \mathrm{m}$ ). 


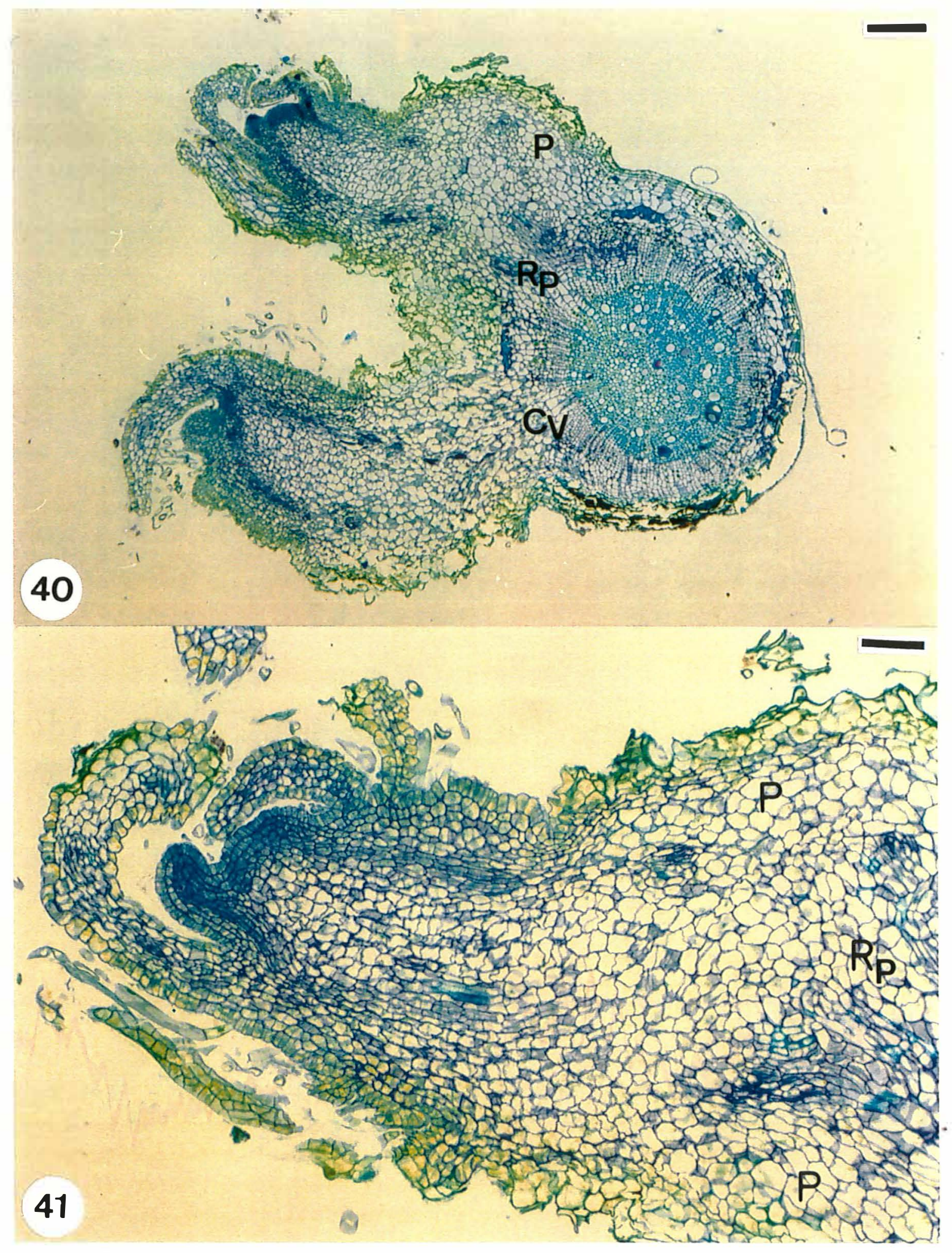


Figuras 42-48 - Microscopia eletrônica de varredura de gemas provenientes da estaca radicular de M. stipitatum. 42-46 - Gemas (setas) em desenvolvimento, promovendo o rompimento da periderme da raiz (barras $=500 \mu \mathrm{m}, 250 \mu \mathrm{m}, 500 \mu \mathrm{m}, 250 \mu \mathrm{m}$ e $200 \mu \mathrm{m}$, respectivamente). 47-48 - Proliferação de células parenquimáticas, na qual uma gema encontra-se associada (barras $=200 \mu \mathrm{m}$ e $50 \mu \mathrm{m}$, respectivamente). 


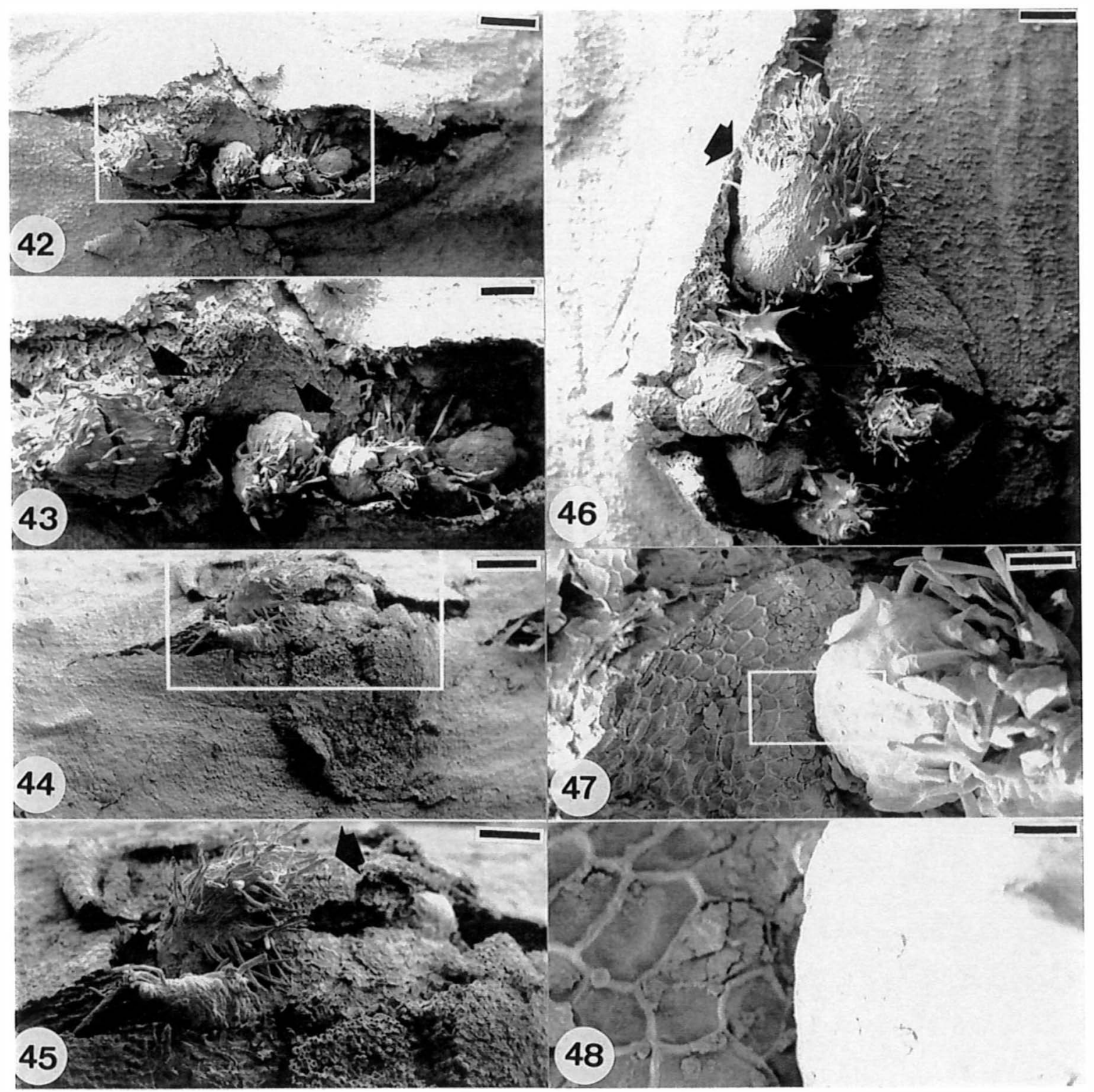


Figuras 49-52 - Secções transversais de estacas radiculares de C. tomentosum. 49 - Secção longitudinal da região superior de uma gema na qual observa-se o ápice meristemático e os primórdios foliares (barra $=552,4 \mu \mathrm{m}$ ). 50 - Detalhe de um outro plano de corte da gema da figura anterior, mostrando a sua porção inferior em estreita associação com o câmbio vascular da raiz-mãe (barra $=102,3 \mu \mathrm{m}$ ). 51 - Detalhe da figura 49, evidenciando a formação de uma cavidade $(\mathrm{C})$ entre os primórdios foliares da gema e os tecidos periféricos obliterados (seta) (barra $=204,6 \mu \mathrm{m}$ ). 52 - Visão geral de outra gema emergindo na superfície da estaca (barra $=552,4 \mu \mathrm{m})$. 


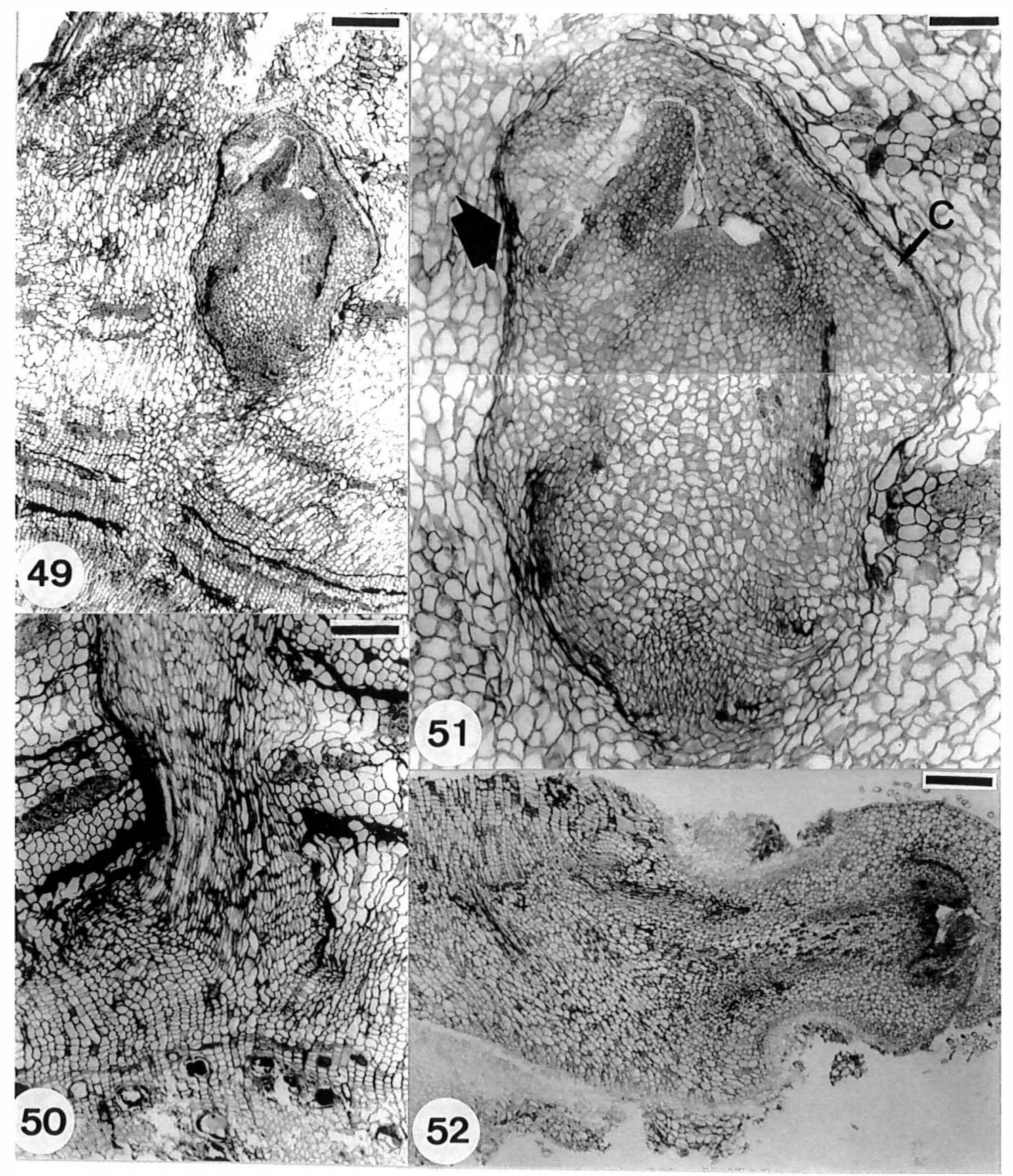


Figura 53 - Variação da temperatura $\left({ }^{\circ} \mathrm{C}\right)$ na superfície das raizes de $C$. tomentosum ( $\mathbf{\Delta})$ e $M$. stipitatum $(\mathbf{O})$, durante a simulação da ação do fogo na indução de gemas. 


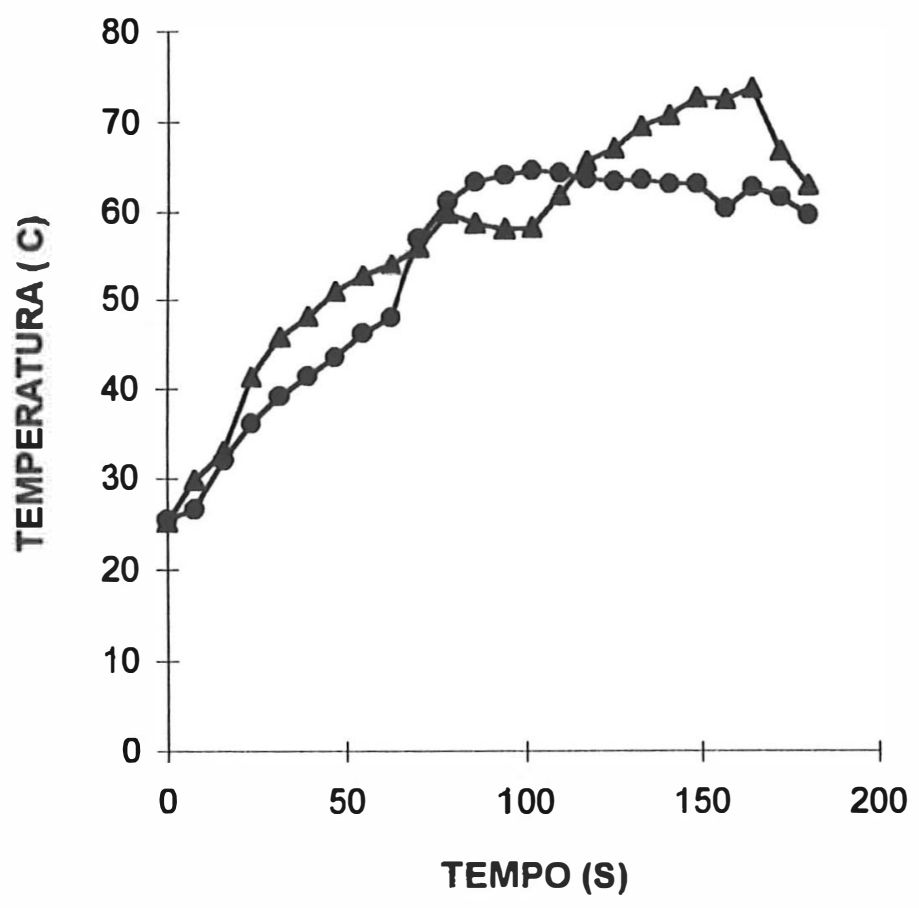


Figuras 54-57 - Estacas radiculares de M. stipitatum. 54 - Gemas formadas nas proximidades de uma raiz lateral ou de sua cicatriz (seta). 55 - Vista frontal do setor indicado na figura anterior. 56 Formação de gemas ao longo da estaca (setas) e na raiz lateral $\left(R_{L}\right)$ da estaca (setas). 57 - Parte aérea formada pelo desenvolvimento de uma gema da estaca radicular. 


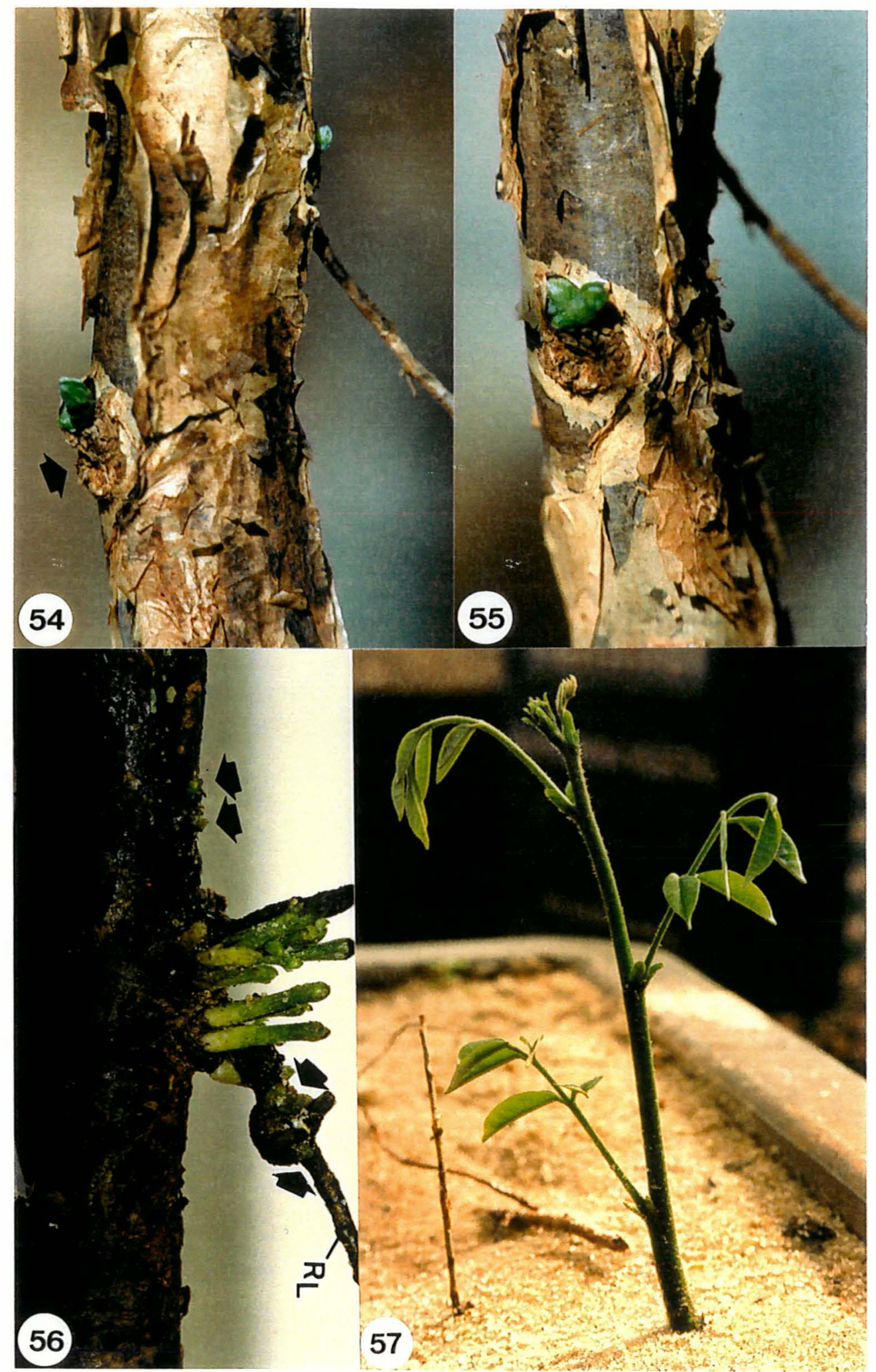


Figuras 58 e 59 - Estacas radiculares de C. tomentosum. 58 - Vista frontal da extremidade proximal da estaca, mostrando a presença de duas gemas radiculares. 59 - Vista lateral de um fragmento da estada radicular, mostrando o aumento do diâmetro da extremidade proximal. 


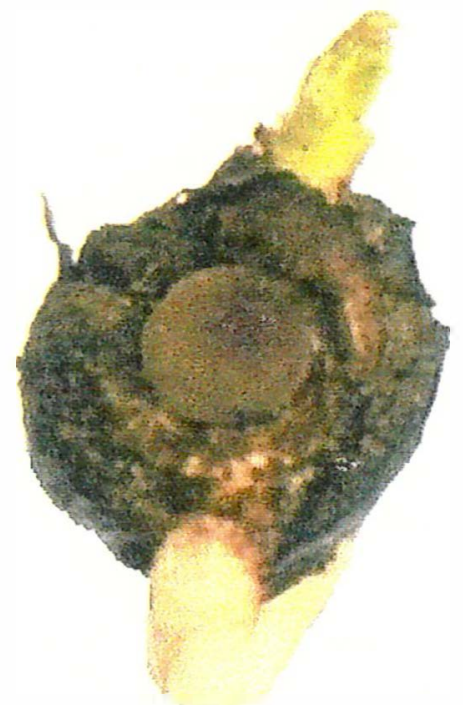

58

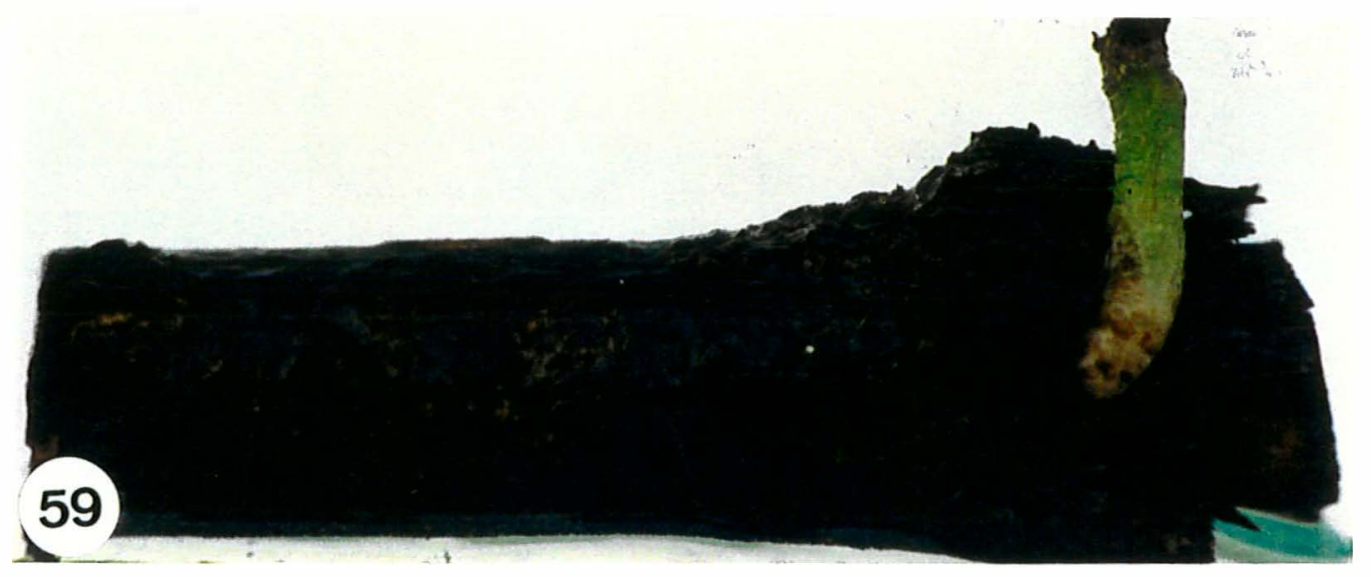

